\title{
Mn(II) complexes with bipyridine, phenanthroline and benzoic acid: Biological and catalase-like activity
}

\author{
IBRAHIM KANI ${ }^{\mathrm{a}, *}$, ÖZLEM ATLIER ${ }^{\mathrm{a}}$ and KIYMET GÜVEN ${ }^{\mathrm{b}}$ \\ ${ }^{a}$ Department of Chemistry, Faculty of Sciences, Anadolu University, Eskişehir, Turkey \\ ${ }^{b}$ Department of Biology, Faculty of Sciences, Anadolu University, Eskişehir, Turkey \\ e-mail: ibrahimkani@anadolu.edu.tr
}

MS received 20 October 2015; revised 19 January 2016; accepted 28 January 2016

\begin{abstract}
Five mononuclear $\mathrm{Mn}(\mathrm{II})$ complexes, $\left[\mathrm{Mn}(\mathrm{phen})_{2}\left(\mathrm{ClO}_{4}\right)_{2}\right](\mathbf{1}),\left[\mathrm{Mn}(\text { phen })_{3}\right]\left(\mathrm{ClO}_{4}\right)_{2}\left(\mathrm{H}_{2} \mathrm{CO}_{3}\right)_{2}(\mathbf{2})$, $\left.\left[\mathrm{Mn}(\text { bipy })_{2}\left(\mathrm{ClO}_{4}\right)_{2}\right](3),\left[\mathrm{Mn}(\text { bipy })_{3}\right]\left(\mathrm{ClO}_{4}\right)_{2}\right)(\mathbf{4})$, and $\left.\mathrm{Mn}(\mathrm{phen})_{2}(\mathrm{ba})\left(\mathrm{H}_{2} \mathrm{O}\right)\right]\left(\mathrm{ClO}_{4}\right)\left(\mathrm{CH}_{3} \mathrm{OH}\right)(\mathbf{5})$, where bipy $=2,2^{\prime}$-bipyridine, phen $=1,10$-phenanthroline, and ba $=$ benzoic acid were prepared and characterized by Xray, IR and UV-Vis spectroscopies, and their catalase-like and biological activities were studied. The presence of two different types and the number of chelating NN-donor neutral ligands allowed for analysis of their effects on the catalase and biological activities. It was observed that the presence and number of phen ligands improved the activity more than the bipy ligand. Complexes $\mathbf{1}$ and $\mathbf{2}$, which contain more basic phen ligands, disproportionate $\mathrm{H}_{2} \mathrm{O}_{2}$ faster than complexes 3 and 4, which contain less basic bipy ligands. The in vitro antimicrobial activities of all the complexes were also tested against seven bacterial strains by microdilution tests. All the bacterial isolates demonstrated sensitivity to the complexes and the antifungal (anticandidal) activities of the $\mathrm{Mn}(\mathrm{II})$ complexes were remarkably higher than the reference drug ketoconazole.
\end{abstract}

Keywords. Manganese complex; catalase; biological activity; hydrogen peroxide; bipyridine; phenanthroline

\section{Introduction}

The synthesis of transition metal complexes that exhibit antimicrobial and catalase activities has gained interest in recent years due to their potential for application as inorganic pharmaceuticals in clinical therapy and diagnostics. ${ }^{1-7}$ An increasing number of mono- and dinuclear $\mathrm{Mn}(\mathrm{III} / \mathrm{II})$ complexes with catalase activity have been reported in the literature, most of them with Schiff base ligands. Following the first publication of the bipy and phen ligands of Mn(II) complexes by Fukuda and Sone in 1970, a large number of such compounds have been reported with different metals using mainly the same ligands with various anions..$^{8-11}$ Because of their potential use as catalytic scavengers of $\mathrm{H}_{2} \mathrm{O}_{2}$ against oxidative stress, several mono- and dinuclear complexes involving different types of ligands have been synthesized and characterized in an attempt to mimic the active sites and catalytic activities of enzymes. ${ }^{12-19}$ While numerous Mn complexes have been synthesized, few systematic studies have explored the effect of the $\mathrm{N}-\mathrm{N}$ chelating coordination of neutral bipy and phen ligands on catalase and biological activity. ${ }^{20-22}$

To investigate the catalase and antimicrobial activities of complexes in this class, we synthesized five

*For correspondence
$\mathrm{Mn}$ (II) complexes using bidentate bipy/phen and benzoic acid (ba) ligands and perchlorate as a counter anion with the general formulae $[\mathrm{Mn}(\mathrm{N}-\mathrm{N})(\mathrm{O})(\mathrm{O})]$, $\left[\mathrm{Mn}(\mathrm{N}-\mathrm{N})_{2}\right]^{2+}$ where $\mathrm{N}, \mathrm{N}$ represents the bidentate diimine ligands bipy and phen; $(\mathrm{O})(\mathrm{O})$ represents the counter ion perchlorate for complexes $\mathbf{1}$ and $\mathbf{3}$ and benzoate for complex 5..$^{23,24}$ The complexes obtained with these ligands had the following compositions: $\left.\left[\mathrm{Mn}(\text { phen })_{2}\left(\mathrm{ClO}_{4}\right)_{2}\right)\right](\mathbf{1}),\left[\mathrm{Mn}(\text { phen })_{3}\right]\left(\mathrm{ClO}_{4}\right)_{2}\left(\mathrm{H}_{2} \mathrm{CO}_{3}\right)_{2}$ (2), $\left.\left[\mathrm{Mn}(\text { bipy })_{2}\left(\mathrm{ClO}_{4}\right)_{2}\right)\right](3),\left[\mathrm{Mn}(\text { bipy })_{3}\right]\left(\mathrm{ClO}_{4}\right)_{2}$ (4) and $\left.\mathrm{Mn}(\mathrm{phen})_{2}(\mathrm{ba})\left(\mathrm{H}_{2} \mathrm{O}\right)\right]\left(\mathrm{ClO}_{4}\right)\left(\mathrm{CH}_{3} \mathrm{OH}\right)(5)$, where bipy $=2,2^{\prime}$-bipyridine, phen $=1,10$-phenanthroline, and $\mathrm{ba}=$ benzoic acid. In addition to crystallographically characterizing these compositions, spectral studies were also carried out. In this work, we examined the chelating effects of phen and bipy with two coordinations of NN chelating atoms in complexes $\mathbf{1}$ and $\mathbf{3}$ and four coordinations of $\mathrm{NN}$ atoms in complexes $\mathbf{2}$ and $\mathbf{4}$, respectively. In addition to $\mathrm{NN}$ chelation, the effect of the second ligand coordination of ba was also tested. Herein, we report the reactivity of complexes 1- 5 with $\mathrm{H}_{2} \mathrm{O}_{2}$ (catalase activity) studied by measuring the volume of the evolved oxygen. Promising results were obtained against the antimicrobial activity of different sets of microorganisms for complexes $\mathbf{1 , 2}$ and $\mathbf{5}$, which may have the potential to be an alternative antifungal drug to ketoconazole. 


\section{Experimental}

\subsection{Materials and Methods}

All chemicals were purchased from Aldrich and were used as received. FT-IR spectra of compounds were recorded on a Jasco FT/IR-300 E spectrophotometer. FT-IR spectra were recorded on a JASSCO FT/IR-300E spectrophotometer using the $\mathrm{KBr}$ pellet technique in the range $4000-400 \mathrm{~cm}^{-1}$. The electronic spectra were recorded on a SHIMADZU UV-2450 spectrophotometer.

\subsection{Synthesis of Compounds}

2.2a $\left[\mathrm{Mn}(\text { phen })_{2}\left(\mathrm{ClO}_{4}\right)_{2}\right], \quad(\mathbf{1}):$ A mixture of $\mathrm{Mn}$ $\left(\mathrm{ClO}_{4}\right)_{2} .6\left(\mathrm{H}_{2} \mathrm{O}\right)(0.100 \mathrm{~g}, 0.276 \mathrm{mmol})$ with phen $(0.099 \mathrm{~g}, 0.552 \mathrm{mmol})$ in methanol (1:2) were stirred for $12 \mathrm{~h}$ at r.t.. The mixture was filtered over celite and the solvent was evaporated to dryness. Yellow crystals were obtained by slow cooling of methanol solution at room temperature. Yield: 47\% (color light yellow, decompose 223-298 C. Significant IR bands $\left(\mathrm{KBr}, \mathrm{cm}^{-1}\right)$ : 3085 (s), 1997 (s), 1612 (s), 1550 8w), 1461 (s), 1103 (vs), 821 (s), 605 (s). Found (\%): N: 9,09; C: 48,05; H: 3.25; Calc. (\%): N: 9,11; C: 48,17; H: 3.06). The complex is soluble in DMF, $\mathrm{MeOH}$, EtOH, $\left(\mathrm{CH}_{3}\right)_{2} \mathrm{CO}, \mathrm{MeCN}$ and slightly soluble in $\mathrm{CH}_{2} \mathrm{Cl}_{2}$.

2.2b $\quad\left[\mathrm{Mn}(\text { phen })_{3}\right]\left(\mathrm{ClO}_{4}\right)_{2}\left(\mathrm{H}_{2} \mathrm{CO}_{3}\right), \quad(2)$ : A mixture of $\mathrm{Mn}\left(\mathrm{ClO}_{4}\right)_{2} .6\left(\mathrm{H}_{2} \mathrm{O}\right)(0.100 \mathrm{~g}, 0.276 \mathrm{mmol})$ with phen $(0.149 \mathrm{~g}, 0.828 \mathrm{mmol})$ in methanol $(1: 3)$ were stirred for $12 \mathrm{~h}$ at r.t.. The mixture was filtered over celite and the solvent was evaporated to dryness. The yellow product was recrystallized from methanol by ether diffusion. Yield: $61 \%$ (color light yellow, M.p. $310^{\circ} \mathrm{C}$. FTIR bands (KBr, cm ${ }^{-1}$ ): 3097 (w), 1978 (w), 1608 (w), 1465 (w), 1091 (vs), 821 (s), 605 (s). Found (\%) N: 9,42; C: 47,12; H: 2.83; Calc. (\%): N: 9.12; C: 46.92; H: 2.63); The complex is soluble in DMF, $\mathrm{MeOH}, \mathrm{EtOH},\left(\mathrm{CH}_{3}\right)_{2} \mathrm{CO}$, $\mathrm{MeCN}$, and slightly soluble in $\mathrm{CH}_{2} \mathrm{Cl}_{2}$.

2.2c $\left[\mathrm{Mn}(\text { bipy })_{2}\left(\mathrm{ClO}_{4}\right)_{2}\right]$, (3): A mixture of $\mathrm{Mn}$ $\left(\mathrm{ClO}_{4}\right)_{2} .6\left(\mathrm{H}_{2} \mathrm{O}\right) \quad(0.100 \mathrm{~g}, 0.276 \mathrm{mmol})$ with bipy $(0.0862 \mathrm{~g}, 0.552 \mathrm{mmol})$ in the molar ratio $1: 2$ and methanol $(20 \mathrm{~mL})$ was placed in a Schlenk vessel $(50 \mathrm{~mL})$. The mixture was refluxed for $4 \mathrm{~h}$. The resulting solution was allowed to stand in air and crystals of the complex $\mathbf{3}$ were deposited after a week (color: green, M.p. $336^{\circ} \mathrm{C}$, $0.91 \mathrm{~g}$, yield 90\%). FTIR (KBr pellet, $\mathrm{cm}^{-1}$ ): 3081 (s), 1997 (m), 1596 (s), 1454 (s), 1280 (w), 1087 (vs), 740 (s), 613 (s). Found (\%) N: 9.64; C: 42.01; H: 3.05;
Calc. (\%): N: 9.89; C: 42.42; H: 2.85). The complex is soluble in $\mathrm{MeOH}$, EtOH, $\mathrm{MeCN},\left(\mathrm{CH}_{3}\right)_{2} \mathrm{CO}$, and slightly soluble in $\mathrm{CH}_{2} \mathrm{Cl}_{2}$.

2.2d $\left.\left[\mathrm{Mn}(\text { bipy })_{3}\right]\left(\mathrm{ClO}_{4}\right)_{2}\right),(4):$ A mixture of $\mathrm{Mn}$ $\left(\mathrm{ClO}_{4}\right)_{2} .6\left(\mathrm{H}_{2} \mathrm{O}\right)(0.100 \mathrm{~g}, 0.276 \mathrm{mmol})$ with bipy $(0.129 \mathrm{~g}, 0.828 \mathrm{mmol})$ in the molar ratio $1: 3$ and methanol $(20 \mathrm{~mL})$ was placed in a Schlenk vessel $(50 \mathrm{~mL})$. The mixture was refluxed for $4 \mathrm{~h}$. The mixture was filtered over celite and the solvent was evaporated to dryness. The yellow product was recrystallized from methanol by ether diffusion. Yield: $86 \%$ (color light yellow, M.p. $315^{\circ} \mathrm{C}$. FTIR bands $\left(\mathrm{KBr}, \mathrm{cm}^{-1}\right)$ : 3073(s), 1994 (s), 1585 (s), 1450 (s), 1280 (w), 1087 (vs), 740 (s), 609 (s). Found (\%) N: 12.04; C: 49.98,05; H: 3.25; Calc. (\%): N: 11.63; C: 49.88; H: 3.35). The complex is soluble in DMSO, DMF, $\mathrm{MeOH}, \mathrm{EtOH},\left(\mathrm{CH}_{3}\right)_{2} \mathrm{CO}$, $\mathrm{MeCN}$, and slightly soluble in $\mathrm{CH}_{2} \mathrm{Cl}_{2}$.

2.2e $\left[\mathrm{Mn}(\mathrm{ba})(\text { phen })_{2}\left(\mathrm{H}_{2} \mathrm{O}\right)\right]\left(\mathrm{ClO}_{4}\right)_{2}\left(\mathrm{CH}_{3} \mathrm{OH}\right), \quad(5)$ : A solution of manganese(II) perchlorate, $\mathrm{Mn}\left(\mathrm{ClO}_{4}\right)_{2}$. $\left.6\left(\mathrm{H}_{2} \mathrm{O}\right), 0.144 \mathrm{~g}, 0.398 \mathrm{mmol}\right)$ in methanol $(10 \mathrm{~mL})$ was added to a neutralized solution of benzoic acid $(0.515$ g, $0.422 \mathrm{mmol}$ ) with $\mathrm{NaOH}(0.1 \mathrm{M}$ solution). The reaction mixture was stirred for $1 \mathrm{~h}$ at room temperature and then the solution of phen $(0.143 \mathrm{mg}, 0.796 \mathrm{mM})$ in methanol $(2 \mathrm{~mL})$ was added to the mixture. The final solution was refluxed for $5 \mathrm{~h}$. The solvent was removed by evaporation and the crude product was washed with diethyl ether, and then dried under vacuum $(0.1954$ $\mathrm{g}, 69 \%$ ). The yellow product was recrystallized from methanol by ether diffusion. M.p. (Dec). $190-192^{\circ} \mathrm{C}$. IR ( $\mathrm{KBr}$ pellet, $\mathrm{cm}^{-1}$ ): 3050 (vs), 1990 (s), 1581 (vs), 1396 (s), 1307 (s), 1083 (vs), 825(s), 694 (s). Found (\%) N: 8.64; C: 58.05; H: 3.25; Calc. (\%): N: 8,17; $\mathrm{C}: 56.03 ; \mathrm{H}: 3.97)$. The complex is soluble in polar solvents, and slightly soluble in $\mathrm{CH}_{2} \mathrm{Cl}_{2}$ and $\mathrm{CHCl}_{3}$.

\subsection{Antimicrobial activity}

Antimicrobial activities of the compounds against a few bacteria namely, Staphylococcus aureus NRRL B-767, Pseudomonas aeruginosa ATCC 254992, Klebsiellapneumoniae NRRL B-4420, Escherichia coli NRRL B3704, Enterococcus faecalis ATCC 29212, Proteus vulgaris NRRL B-123, Listeria monocytogenes ATCC 7644, and Candida species, namely, Candida tropicalis NRRL Y-12968, Candida krusei NRRL Y-7179, Candida zeylanoides NRRL Y-1774, Candida parapsilosis NRRL Y- 12696, Candida albicans ATCC 90028 and Candida globrata NRRL Y-17815, were expressed as 
the minimum inhibitory concentration (MIC). The test strains were obtained from the American Type Culture Collection (ATCC) and Agricultural Research Service Culture Collection (ARS).

The minimal inhibitory concentration (MIC) values of the compounds were determined by the micro dilution testing protocol. ${ }^{25}$ The stock solutions of the compounds were prepared in DMSO. Chloramphenicol was used as the standard antibacterial agent whereas ketoconazole was used as an antifungal agent. The antimicrobial activity of the compounds and control drugs were recorded as MIC values, in $\mu \mathrm{g} / \mathrm{mL}$.

\subsection{Hydrogen peroxide disproportionation studies}

Volumetric measurements of the oxygen evolved during the reaction of the $\mathrm{Mn}$ (II) complexes with $\mathrm{H}_{2} \mathrm{O}_{2}$ was carried out as follows: A $50 \mathrm{~mL}$, twonecked round-bottom flask containing a solution of the complex in solvent was placed in a water bath $\left( \pm 0.2^{\circ} \mathrm{C}\right)$. One of the necks was connected to a graduated burette filled with water and the other was stoppered with a rubber septum. The solution was stirred for 10 min to reach a stable temperature. While the solution was stirring, a chosen volume of $\mathrm{H}_{2} \mathrm{O}_{2}$ stock solution was injected into the flask through the rubber septum using a syringe, and the volume of evolved oxygen was measured with the burette as a function of time.

\section{$2.5 X$-ray crystallography}

Diffraction data for the complex were collected with Bruker AXS APEX CCD diffractometer equipped with a rotating anode at 296(2) $\mathrm{K}$ using graphite monochromated Mo K $\alpha$ radiation at $\lambda=0.71073 \AA$. Diffraction data were collected over the full sphere and were corrected for absorption. Unit cell dimensions were determined by least-squares refinement of the complete data set and an empirical absorption correction was made based on psi-scans. The data reduction was performed with the Bruker SMART program package. ${ }^{26}$ For further crystal and data collection details, see table 1 . Structure solution was found with the SHELXS- $97^{27}$ package using the direct methods and were refined SHELXL-97 ${ }^{28}$ against $F^{2}$ using first isotropic and later, anisotropic thermal parameters for all non-hydrogen atoms. Hydrogen atoms were added to the structure model at calculated positions. Geometric calculations were performed with PLATON. ${ }^{29}$

\section{Results and Discussion}

\subsection{Synthesis of the complexes}

The synthesis of the complexes is shown in scheme 1 . $\mathrm{X}$-ray analysis and spectral data confirm the assigned compositions of the complexes. The electronic spectra of the complexes were taken in methanol. The same ligand and metal give different complexes because the structure of the complexes depends strongly on the mole ratio of metal to ligand in the reaction medium. Only harvested crystals of the complexes were used for catalase and the biological activity studies to exclude the effects of impurities.

\subsection{Spectroscopic study of the complexes}

Complexes 1-5 share some similar features in the IR spectra resulting from the skeletal vibrations of aromatic rings, exhibiting a strong band at approximately $1599-1576 \mathrm{~cm}^{-1}(\mathrm{C}=\mathrm{N}$ and $\mathrm{C}=\mathrm{C}$ stretches), 1476-1048 $\mathrm{cm}^{-1}$ (C $-\mathrm{C}$ and $\mathrm{C}-\mathrm{N}$ vibrations), and 920-737 $\mathrm{cm}^{-1}$ (aromatic C-H deformation vibrations) (figure S1 in Supplementary Information). The coordination of bipy / phen to the manganese through the nitrogen atoms is indicated by the positive shift of the $(\mathrm{C}=\mathrm{C})$ and $(\mathrm{C}=\mathrm{N})$ ring stretching frequencies, which are $8-25 \mathrm{~cm}^{-1}\left(\sim 1600\right.$ and $\left.1550 \mathrm{~cm}^{-1}\right)$ lower in the free ligand $\left(1586 \mathrm{~cm}^{-1}\right.$ and $\left.1454 \mathrm{~cm}^{-1}\right)$, respectively. The strong non-splitting absorption band of uncoordinated perchlorate anions (at approximately $1100 \mathrm{~cm}^{-1}$ and $620 \mathrm{~cm}^{-1}$ ) is distinctly split into 2 components, which are observed at approximately 1029 and $1138 \mathrm{~cm}^{-1}$ and $624-630 \mathrm{~cm}^{-1}$. These features indicate monodentate coordination of the perchlorate group..$^{30-32}$ In the case of complexes $\mathbf{2}$ and $\mathbf{4}$, the observed broad unsplit bands at ca. $1100 \mathrm{~cm}^{-1}$ and $630 \mathrm{~cm}^{-1}$ are indicative of the presence of uncoordinated perchlorate ions.

The coordination of deprotonated benzoic acid to manganese was observed by the shifting of $v_{\mathrm{C}-\mathrm{O}}$ from $1682 \mathrm{~cm}^{-1}$ and $1453 \mathrm{~cm}^{-1}$ in the free ligand to 1581 $\mathrm{cm}^{-1}$ and $1396 \mathrm{~cm}^{-1}$, which are assigned to the asymmetrical and symmetrical COO vibrational modes, respectively. Moreover, the difference between these two bands $\left(185 \mathrm{~cm}^{-1}\right)$ indicates that the carboxylate is acting in unidentate mode. The decrease in the $v_{\mathrm{C}-\mathrm{O}}$ frequency in complex $\mathbf{5}$ clearly indicated that the binding of deprotonated ligand to the metal center, and the decreases in $v_{\mathrm{C}-\mathrm{O}}$ were due to the generation of partial double bond character in the carbonyl moiety after complex formation.

The UV-Vis spectroscopic data are very similar for all of the complexes, indicating that the $\mathrm{Mn}$ (II) 


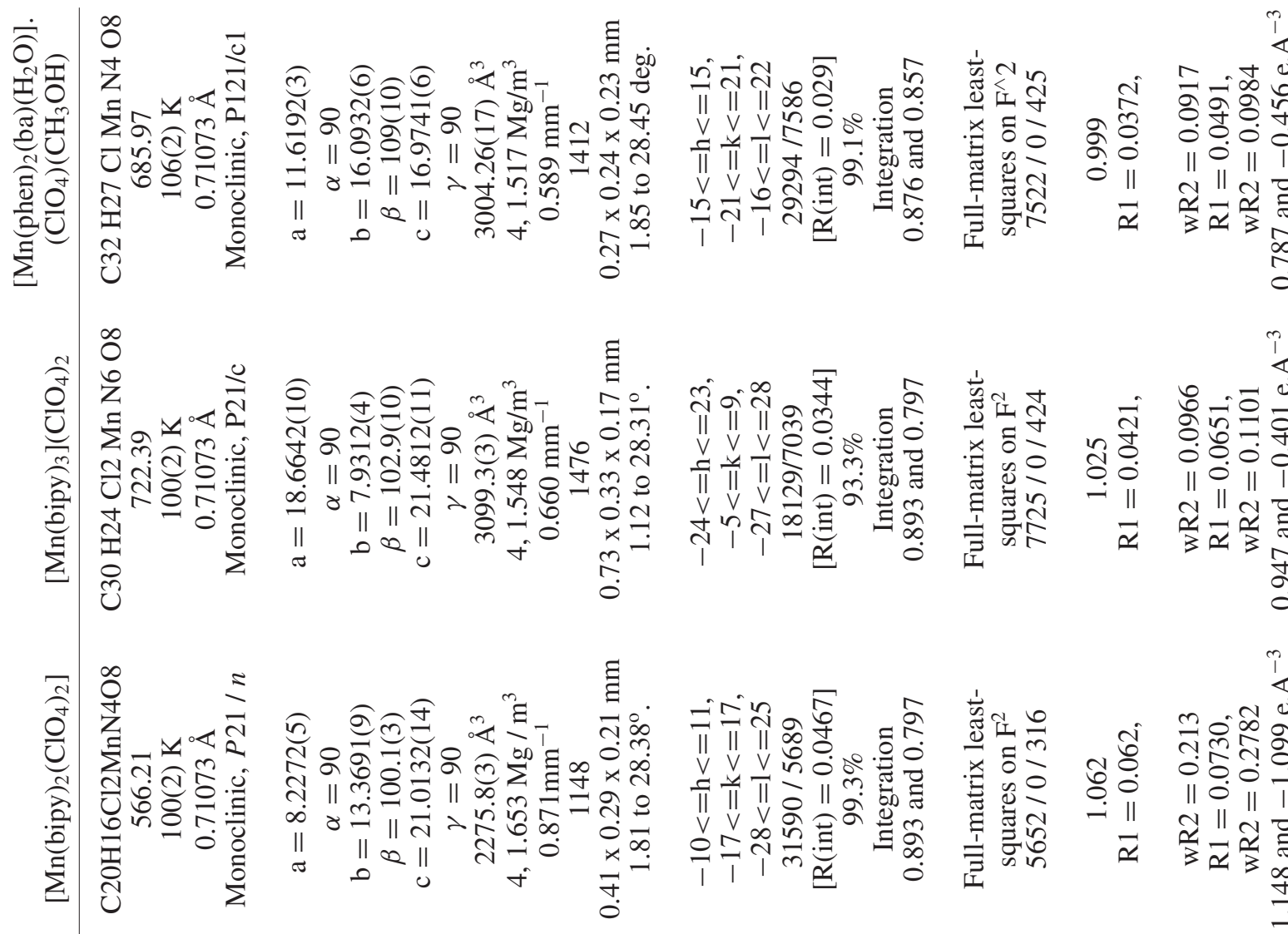

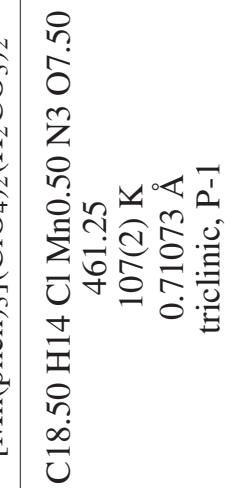

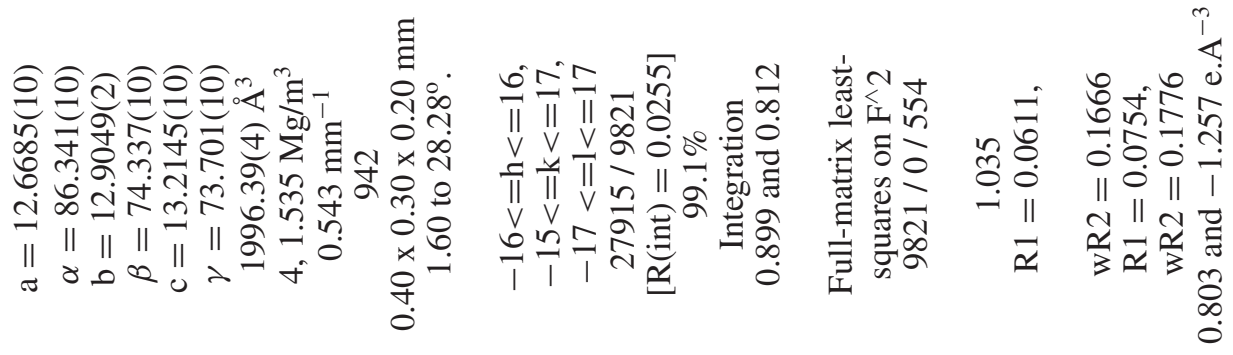

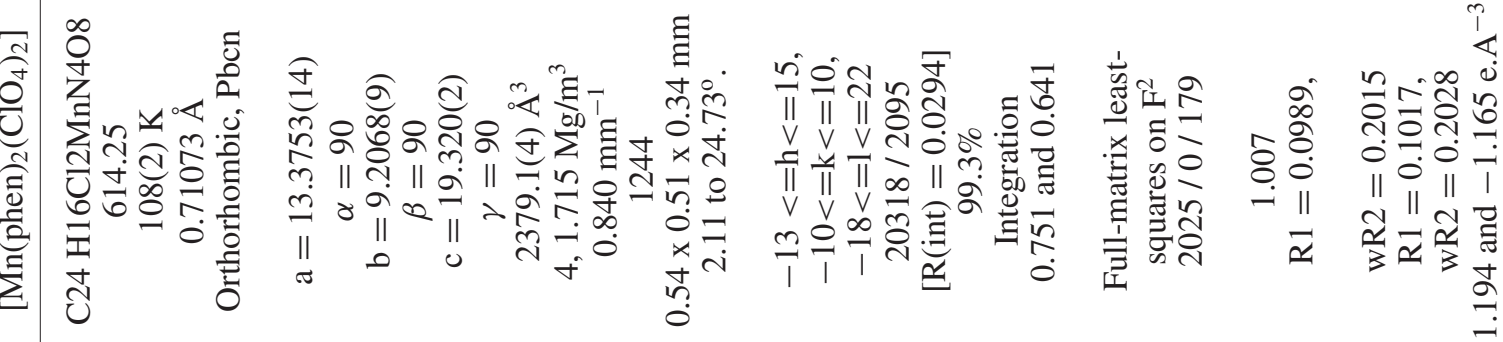

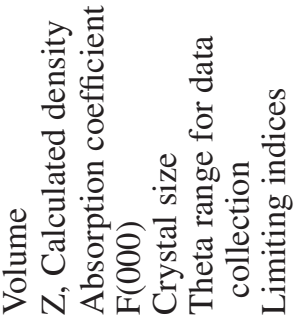

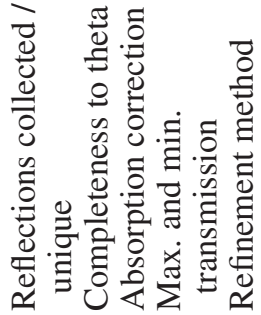

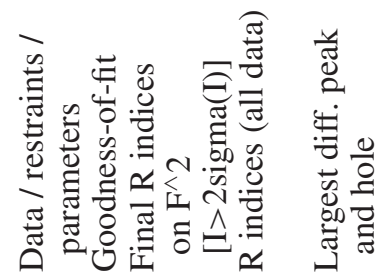


2

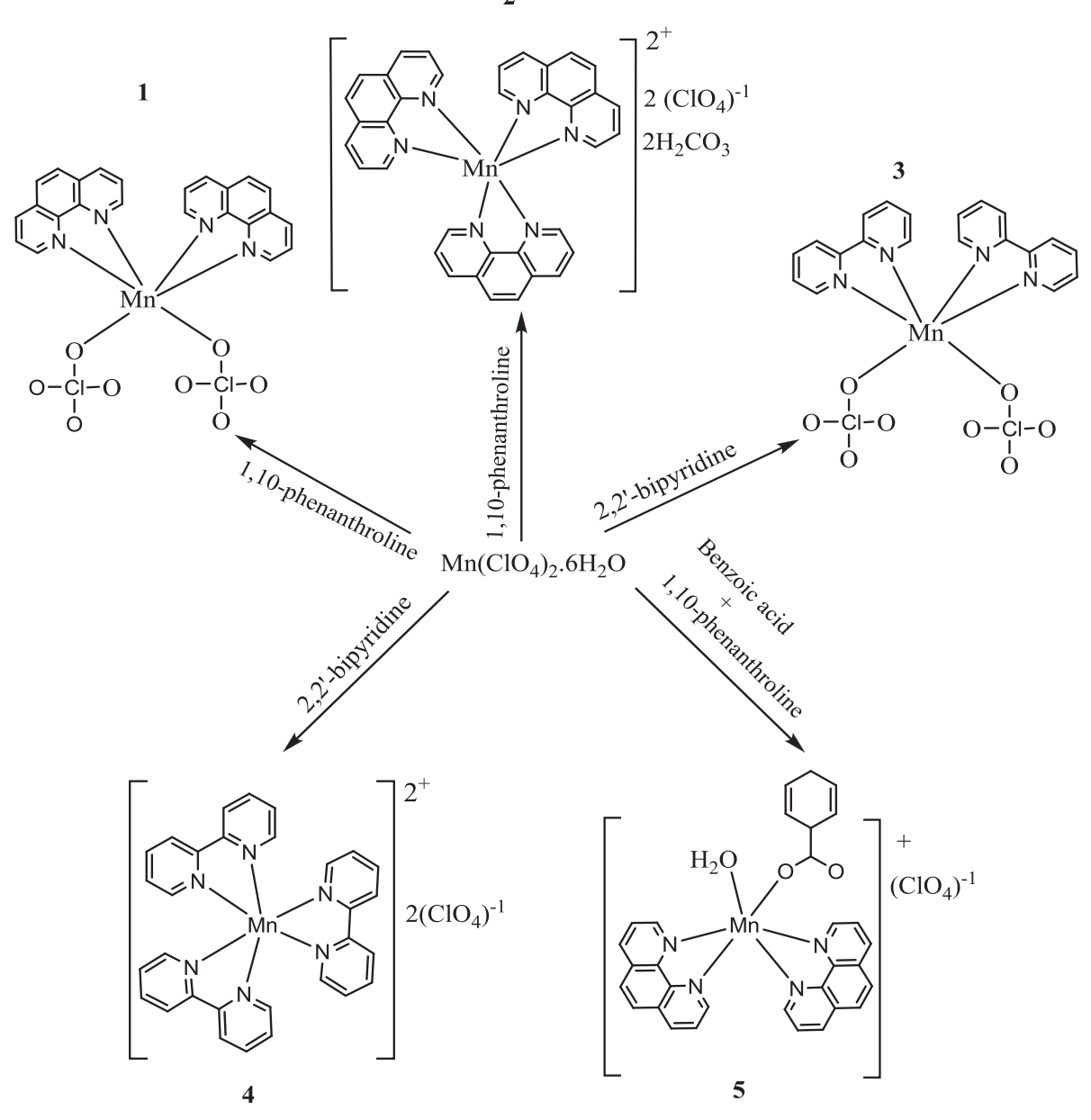

Scheme 1. Synthesis of $\mathrm{Mn}(\mathrm{II})$ complexes $\mathbf{1} \mathbf{- 5}$.

complexes are behaving as a high spin octahedral $\mathrm{d}^{5}$ system (See figures in SI). The absorption bands in the UV region at 235, 280, 229 and $264 \mathrm{~nm}$ are assigned to ligand-centered $\pi \rightarrow \pi^{*}$ or $\mathrm{n} \rightarrow \pi^{*}$ transitions in the bipy and phen ligands, respectively. Due to the $\mathrm{d}^{5}$ configuration of the $\mathrm{Mn}^{2+}$ ion, no absorption is expected in the visible region of the spectrum.

\subsection{Description of Crystal Structures}

The crystal data, selected bond lengths/angles and hydrogen bonding interaction parameters for complexes 1-5 are listed in tables 1, 2 and 3.

3.3a $\left[\mathrm{Mn}(\text { bipy })_{2}\left(\mathrm{ClO}_{4}\right)_{2}\right]$ (3) and $\left[\mathrm{Mn}(\text { phen })_{2}\left(\mathrm{ClO}_{4}\right)_{2}\right]$ (1): Complexes $\mathbf{1}$ and $\mathbf{3}$ crystallize in the orthorhombic space group $\mathrm{Pbcn}(\mathrm{Z}=4)$ and the monoclinic space group $\mathrm{P} 21 / \mathrm{n}(\mathrm{Z}=4)$, respectively. The $\mathrm{X}$-ray crystal structures of $\mathbf{1}$ (figure 1a) and $\mathbf{3}$ (figure $1 \mathrm{~b}$ ) are discussed together below. The similarity between the structure of complex $\mathbf{3}^{33-37}$ and complex $\mathbf{1}^{38,39}$ has been reported previously by others. Our group has reported detailed structure analysis of complex $\mathbf{1}$ and has also worked with it as a catalyst for alcohol oxidation. ${ }^{40}$

In each structure, the manganese ion is sixcoordinated, but the geometry is far from octahedral, principally due to the bite angle of the bipy and phen ligands. The manganese ion in cis-Mn(bipy) $\left(\mathrm{ClO}_{4}\right)_{2}$ (3) sits on a two-fold axis, whereas cis-Mn(phen $)_{2}$ $\left(\mathrm{ClO}_{4}\right)_{2}(2)$ has no internal crystallographic symmetry. In spite of this result, the geometries of the two complexes are very similar (figure 1). The 5-membered chelating rings of $\mathrm{Mn}(\mathrm{II})$ and $\mathrm{N}$ atoms of phen exhibit nearly perfect coplanarity; the N1- C5 - C6 - N2 torsion angle is $0(1)^{\circ}$ for complex $\mathbf{1}$. The mean planes of the two phen molecules are inclined at $69.51^{\circ}$ $(\mathrm{N} 2 \cdots \mathrm{N} 1$ and $\mathrm{N} 5 \cdots \mathrm{N} 6), 80.44^{\circ}(\mathrm{N} 3 \cdots \mathrm{N} 4$ and $\mathrm{N} 5 \cdots \mathrm{N} 6)$ and $70.33^{\circ}(\mathrm{N} 2 \cdots \mathrm{N} 1$ and $\mathrm{N} 3 \cdots \mathrm{N} 4)$ with respect to one another. The 5-membered chelating rings of $\mathrm{Mn}(\mathrm{II})$ and $\mathrm{N}$ atoms of bipy are considerably planar for complex 3; the N1 - C5 - C6 - N2 and N4 $\mathrm{C} 15-\mathrm{C} 16-\mathrm{N} 4$ torsion angles are $2.3(5)^{\circ}$ and $6.4(4)^{\circ}$, respectively. 
Table 2. Selected bond lengths $(\AA)$ and angles $\left(^{\circ}\right)$ for the complexes $\mathbf{1}-\mathbf{5}$.

\begin{tabular}{|c|c|c|c|}
\hline \multicolumn{4}{|l|}{1} \\
\hline Mn1 - O1 & 2.2019 & O1 - Mn1- N1 & 94.28 \\
\hline Mn1 - N1 & 2.2446 & $\mathrm{O} 1$ - Mn1- N2 & 88.93 \\
\hline Mn1 - N2 & 2.2307 & N1 - Mn1- N2 & 94.87 \\
\hline Cl1 - O1 & 1.4586 & Mn1-O1- Cl1 & 135.90 \\
\hline $\mathrm{Cl} 1$ - O2 & 1.4078 & Mn1- N1- C2 & 127.40 \\
\hline \multirow[t]{2}{*}{ N1 - C2 } & 1.3357 & Mn1- N2 - C6 & 114.73 \\
\hline & & Mn1- N2 - C7 & 128.56 \\
\hline \multicolumn{4}{|l|}{2} \\
\hline$N(2)-M n(1)$ & $2.248(2)$ & $N(6)-M n(1)-N(1)$ & $162.52(9)$ \\
\hline$N(4)-M n(1)$ & $2.249(2)$ & $N(1)-M n(1)-N(2)$ & $74.64(9)$ \\
\hline$M n(1)-N(6)$ & $2.237(2)$ & $\mathrm{N}(2)-\mathrm{Mn}(1)-\mathrm{N}(4)$ & $157.87(9)$ \\
\hline $\operatorname{Mn}(1)-N(1)$ & $2.242(2)$ & $\mathrm{N}(6)-\mathrm{Mn}(1)-\mathrm{N}(5)$ & $73.85(9)$ \\
\hline $\mathrm{Mn}(1)-\mathrm{N}(5)$ & $2.273(2)$ & $\mathrm{N}(1)-\mathrm{Mn}(1)-\mathrm{N}(3)$ & $103.41(9)$ \\
\hline $\operatorname{Mn}(1)-N(3)$ & $2.291(2)$ & $N(4)-M n(1)-N(3)$ & $73.62(9)$ \\
\hline \multicolumn{4}{|l|}{3} \\
\hline Mn1 - O8 & $2.193(3)$ & O8 - Mn1 -O1 & $77.26(10)$ \\
\hline Mn1 - N4 & $2.205(3)$ & $\mathrm{O} 8$ - Mn1 - N2 & $156.84(10)$ \\
\hline Mn1 - N2 & $2.206(3)$ & N2 - Mn1 - O1 & $87.89(9)$ \\
\hline Mn1 - N3 & $2.218(3)$ & N3 - Mn1 - O1 & $168.74(9)$ \\
\hline Mn1 - N1 & $2.219(3)$ & N4 - Mn1 - N1 & $169.12(10)$ \\
\hline Mn1 - O1 & $2.279(2)$ & N4 - Mn1 - N3 & $74.21(10)$ \\
\hline \multicolumn{4}{|l|}{4} \\
\hline$M n(1)-N(5)$ & $2.214(2)$ & N1 - Mn1 - N5 & 164.48 \\
\hline $\operatorname{Mn}(1)-N(3)$ & $2.214(2)$ & N1 - Mn1 -N2 & 73.08 \\
\hline $\mathrm{Mn}(1)-\mathrm{N}(4)$ & $2.215(2)$ & N3 - Mn1 - N4 & 74.61 \\
\hline $\operatorname{Mn}(1)-N(1)$ & $2.235(2)$ & N3 - Mn1 -N5 & 101.36 \\
\hline $\mathrm{Mn}(1)-\mathrm{N}(6)$ & $2.277(2)$ & N3 - Mn1 - N6 & 175.13 \\
\hline $\mathrm{Mn}(1)-\mathrm{N}(2)$ & $2.277(2)$ & N5 - Mn1 -N6 & 73.92 \\
\hline \multicolumn{4}{|l|}{5} \\
\hline $\mathrm{Mn}(1)-\mathrm{O}(1)$ & $2.1078(12)$ & $\mathrm{O}(1)-\mathrm{Mn}(1)-\mathrm{O}(8)$ & $86.51(5)$ \\
\hline $\mathrm{Mn}(1)-\mathrm{O}(8)$ & $2.1623(14)$ & $\mathrm{O}(8)-\mathrm{Mn}(1)-\mathrm{N}(3)$ & $163.19(5)$ \\
\hline $\operatorname{Mn}(1)-N(3)$ & $2.2618(15)$ & $\mathrm{O}(1)-\mathrm{Mn}(1)-\mathrm{N}(4)$ & $103.45(5)$ \\
\hline $\mathrm{Mn}(1)-\mathrm{N}(4)$ & $2.2686(15)$ & $\mathrm{N}(3)-\mathrm{Mn}(1)-\mathrm{N}(4)$ & $73.38(5)$ \\
\hline $\mathrm{Mn}(1)-\mathrm{N}(2)$ & $2.2693(15)$ & $\mathrm{O}(8)-\mathrm{Mn}(1)-\mathrm{N}(1)$ & $102.83(5)$ \\
\hline $\mathrm{Mn}(1)-\mathrm{N}(1)$ & $2.2776(14)$ & $\mathrm{N}(4)-\mathrm{Mn}(1)-\mathrm{N}(1)$ & $161.21(5)$ \\
\hline
\end{tabular}

The phen ligands show no unusual features. The variations in the $\mathrm{C}-\mathrm{N}$ and $\mathrm{C}-\mathrm{C}$ lengths (table 2) are closely parallel in each ring and follow the pattern observed in other phen and bipy complexes. The $\mathrm{N}(1)-$ $\mathrm{Mn}(1)-\mathrm{N}(2)$ chelating angle is equal to $74.7(2)^{\circ}$ and is similar to those observed in $\mathrm{Mn}$ (II)-phen complexes. In addition, in both cases of these non-covalent interactions, a $\pi-\pi$ interaction is also observed between parallel bipy/phen rings on adjacent chains with a separation of $3.68 \AA$ for complex 1 and $3.984 \AA$ for complex $3{ }^{41}$ The analysis indicates that the crystal packing of $\mathbf{1}$ and $\mathbf{3}$ are formed via hydrogen bonding and weak $\mathrm{C}-\mathrm{H} \cdots \pi$ interactions. In nitrogencontaining molecules, the inductive effect of neutral or charged $\mathrm{N}$ atoms decreases the electron density in adjacent $\mathrm{CH}$ groups ( $\mathrm{C}$ atoms) and enhances the facility with which they participate in $\mathrm{C}-\mathrm{H} \cdots \mathrm{X}$ hydrogen bonds because, in general, they are the shortest ones. In the present case, all $\mathrm{C}$ atoms participate in hydrogen bonds with oxygen atoms of the perchlorate ion, some of which are presented in table 3.

Nonclassical $\mathrm{C}_{\text {bipy }}-\mathrm{H} \cdots \mathrm{O}$ hydrogen bonds (average $\mathrm{C}-\mathrm{O}$ distance $=3.280(9) \AA$ ) link adjacent columns to form the resulting 3D network. The shortest $\pi \cdots H$ distance is $3.140 \AA$ for 3. The shortest $\mathrm{Mn} \cdots \mathrm{Mn}$ interaction is 7.864 (8) $\AA$ for 3 .

\section{3b Structure of $\left.\left[\mathrm{Mn}(\text { phen })_{3}\right]\left(\mathrm{ClO}_{4}\right)_{2}\right)_{2}\left(\mathrm{H}_{2} \mathrm{CO}_{3}\right)(2)$ :} Complex 2 crystallizes in the triclinic space group P-1 $(\mathrm{Z}=4)$. Complex 2 consists of the $\left[\mathrm{Mn}(\mathrm{phen})_{3}\right]^{2+}$ complex cation, two uncoordinated carbonic acids and two perchlorate molecules as counter ions (figure 2a). In the cation, the $\mathrm{Mn}$ (II) atom is coordinated by six $\mathrm{N}$ atoms from three phen molecules to complete a distorted ZnN6 octahedral geometry. All of the Mn - N bond distances are almost equal and in good agreement with previous reports. The $\mathrm{Mn}-\mathrm{N}$ bond lengths are in the range of 2.238 (3)-2.291 (2) $\AA$ (table 2). The phen groups exhibit their usual acute $\mathrm{N} \cdots \mathrm{N}$ bite distances $(\mathrm{N} 1 \cdots \mathrm{N} 2=2.722(4) \AA, \mathrm{N} 3 \cdots \mathrm{N} 4=2.721(4) \AA$, and $\mathrm{N} 5 . . \mathrm{N} 6=2.710(4) \AA$ ) and $\mathrm{N}-\mathrm{Mn}-\mathrm{N}$ bite angles $\left(\mathrm{N} 1-\mathrm{Mn} 1-\mathrm{N} 2=74.63(9)^{\circ}, \mathrm{N} 3-\mathrm{Mnl}-\mathrm{N} 4=\right.$ $73.63(9)^{\circ}$ and $\left.\mathrm{N} 5-\mathrm{Mnl}-\mathrm{N} 6=73.85(9)^{\circ}\right)$. The 5membered chelating rings of $\mathrm{Mn}$ (II) and the $\mathrm{N}$ atoms of phen exhibit nearly perfect coplanarity; the $\mathrm{N} 1-\mathrm{C} 12$ $-\mathrm{C} 11-\mathrm{N} 2$ and N3 - C24 - C23 - N4 and N5 $\mathrm{C} 35$ - C36 - N6 torsion angles are $3.5(4)^{\circ}, 0.1(4)^{\circ}$, and $-2.3(4)^{\circ}$, respectively. The mean planes of the two phen molecules are inclined at $69.51^{\circ}(\mathrm{N} 2 \cdots \mathrm{N} 1$ and $\mathrm{N} 5 \cdots \mathrm{N} 6), 80.44^{\circ}(\mathrm{N} 3 \cdots \mathrm{N} 4$ and $\mathrm{N} 5 \cdots \mathrm{N} 6)$ and $70.33^{\circ}$ $(\mathrm{N} 2 \cdots \mathrm{N} 1$ and $\mathrm{N} 3 \cdots \mathrm{N} 4)$ with respect to one another. The bond distances of the three phen molecules are normal within the range 1.326(4) - 1.363(4) A for aromatic $\mathrm{N}-\mathrm{C}$ bonds.

No classical hydrogen bonding was found in the crystal structure. Furthermore, the host perchlorate anion stabilizes the structure via $\mathrm{C}-\mathrm{H} \cdots \mathrm{O}$ hydrogen bonds (table 3). The perchlorate group acts as a 4-hydrogenbond acceptor for the phen hydrogen. The closest intermolecular contact is observed between the carbon atom (C8) of phen and the oxygen atoms of perchlorate O5 (3.276 ̊). $\mathrm{C}_{\text {bipy }}-\mathrm{H}$. . O hydrogen bonds [average $\mathrm{C}-\mathrm{O}$ distance $=3.370 \AA$ ] link adjacent columns to form the resulting $3 \mathrm{D}$ network. The shortest centroidcentroid distance of two parallel phen ligands is $3.740 \AA$.

3.3c $\left.\left[\mathrm{Mn}(\text { bipy })_{3}\right]\left(\mathrm{ClO}_{4}\right)_{2}\right)$ (4): Complex 4 crystallizes in the monoclinic space group $\mathrm{P} 21 / \mathrm{c}(Z=4)$. Complex 4 consists of a $\left[\mathrm{Mn}(\text { bipy })_{3}\right]^{2+}$ complex cation and a water molecule (figure $2 b$ ). In the cation, the 
Table 3. Selected hydrogen parameters $\left(\AA{ }^{\circ}\right)$, for complexes 1- 5.

\begin{tabular}{|c|c|c|c|c|}
\hline $\mathrm{D}-\mathrm{H}^{\cdots} \mathrm{A}$ & $\mathrm{D}-\mathrm{H}$ & $\mathrm{H}^{\cdots} \mathrm{A}$ & $\mathrm{D} \cdots \mathrm{A}$ & $\mathrm{D}-\mathrm{H}^{\cdots} \mathrm{A}$ \\
\hline \multicolumn{5}{|l|}{1} \\
\hline $\mathrm{C} 3-\mathrm{H} 3 \cdots \mathrm{O}^{\mathrm{i}}$ & 0.95 & 2.433 & 3.381 & 176 \\
\hline $\mathrm{C} 12-\mathrm{H} 12 \cdots \mathrm{O} 2^{\mathrm{i}}$ & 1.08 & 2.486 & 3.421 & 168 \\
\hline $\mathrm{C} 11-\mathrm{H} 11 \cdots \mathrm{O} 3^{\mathrm{ii}}$ & 1.08 & 2.519 & 3.344 & 145 \\
\hline \multicolumn{5}{|c|}{ Symmetry codes: (i) $\mathrm{x},-\mathrm{y},+\mathrm{z}+1 / 2$ (ii) $\mathrm{x}-1 / 2,+\mathrm{y}-1 / 2,-\mathrm{z}+1 / 2$} \\
\hline \multicolumn{5}{|l|}{2} \\
\hline $\mathrm{C} 13-\mathrm{H} 13 \cdots \mathrm{N} 2$ & 0.95 & 2.710 & 3.289 & 119 \\
\hline $\mathrm{C} 33-\mathrm{H} 33 \cdots \mathrm{O} 8$ & 0.95 & 2.354 & 3.216 & 150 \\
\hline $\mathrm{C} 15-\mathrm{H} 15 \cdots \mathrm{O}^{\mathrm{i}}$ & 0.95 & 2.540 & 3.448 & 160 \\
\hline $\mathrm{C} 8-\mathrm{H} 8 \cdots \mathrm{O}^{\mathrm{ii}}$ & 0.95 & 2.335 & 3.276 & 170 \\
\hline C6 - H6 . O O8 $8^{\mathrm{ii}}$ & 0.95 & 2.481 & 3.402 & 163 \\
\hline $\mathrm{C} 29-\mathrm{H} 29 \ldots \mathrm{O}^{\mathrm{iii}}$ & 0.95 & 2.499 & 3.354 & 149 \\
\hline \multicolumn{5}{|c|}{$\begin{array}{l}\text { Symmetry codes: (i) }-\mathrm{x}+1,-\mathrm{y}+2,-\mathrm{z}+1 \text { (ii) } \mathrm{x},+\mathrm{y},+\mathrm{z}+1 \\
\text { (iii) } \mathrm{x}+1,+\mathrm{y},+\mathrm{z}\end{array}$} \\
\hline \multicolumn{5}{|l|}{3} \\
\hline $\mathrm{C} 1-\mathrm{H} 1 \cdots \mathrm{O} 7$ & 0.95 & 2.65 & 3.506 & 149 \\
\hline $\mathrm{C} 1-\mathrm{H} 1 \cdots \mathrm{O} 8$ & 0.95 & 2.66 & 3.179 & 114 \\
\hline $\mathrm{C} 14-\mathrm{H} 1 \cdots \mathrm{O} 4^{\mathrm{i}}$ & 0.95 & 2.68 & 3.613 & 166 \\
\hline $\mathrm{C} 17-\mathrm{H} 17 \mathrm{~A} \cdots \mathrm{O} 4^{\mathrm{i}}$ & 0.95 & 2.52 & 3.465 & 172 \\
\hline $\mathrm{C} 10-\mathrm{H} 10 \cdots \mathrm{O}^{\mathrm{ii}}$ & 0.95 & 2.59 & 3.349 & 136 \\
\hline $\mathrm{C} 3-\mathrm{H} 3 \cdots \mathrm{O}^{\mathrm{iii}}$ & 0.95 & 2.64 & 3.277 & 124 \\
\hline $\mathrm{C} 13-\mathrm{H} 13 \cdot \mathrm{O}^{\mathrm{iv}}$ & 0.95 & 2.69 & 3.231 & 116 \\
\hline $\mathrm{C} 18-\mathrm{H} 18 \cdots \mathrm{O}^{\mathrm{V}}$ & 0.95 & 2.41 & 3.238 & 145 \\
\hline $\mathrm{C} 19-\mathrm{H} 19 \ldots \mathrm{O}^{\mathrm{v}}$ & 0.95 & 2.69 & 3.418 & 133 \\
\hline $\mathrm{C} 7-\mathrm{H} 7 \mathrm{~A} \cdots \mathrm{O} 3^{\mathrm{vi}}$ & 0.95 & 2.46 & 3.384 & 162 \\
\hline
\end{tabular}

Symmetry codes: (i) $\mathrm{x}+1 / 2,-\mathrm{y}+1 / 2,+\mathrm{z}+1 / 2$ (ii) $-\mathrm{x}+1 / 2,+\mathrm{y}+1 / 2$, $-\mathrm{z}+1 / 2$ (iii) $-\mathrm{x},-\mathrm{y},-\mathrm{z}$ (iv) $\mathrm{x}-1 / 2,-\mathrm{y}+1 / 2,+\mathrm{z}+1 / 2(\mathrm{v})-\mathrm{x}+1 / 2,+\mathrm{y}$ $+1 / 2,-\mathrm{z}+1 / 2$ (vi) $\mathrm{x}-1,+\mathrm{y},+\mathrm{z}$

$\begin{array}{lllll}\mathbf{4} & & & & \\ \mathrm{C} 14-\mathrm{H} 14 \cdots \mathrm{O} 1 & 0.95 & 2.381 & 3.322 & 170 \\ \mathrm{C} 30-\mathrm{H} 30 \cdots 7^{\mathrm{i}} & 0.95 & 2.556 & 3.329 & 121 \\ \mathrm{C} 13-\mathrm{H} 13 \cdots{ }^{\mathrm{ii}} & 0.95 & 2.501 & 3.101 & 118 \\ \mathrm{C} 10-\mathrm{H} 10 \cdots \mathrm{O}^{\mathrm{iii}} & 0.95 & 2.352 & 3.147 & 141 \\ \mathrm{C} 8-\mathrm{H} 8 \cdots \text { O6 }^{\text {iv }} & 0.95 & 2.349 & 3.287 & 169\end{array}$

Symmetry codes: (i) $\mathrm{x},-\mathrm{y}+1 / 2,+\mathrm{z}-1 / 2$ (ii) $-\mathrm{x}+1,+\mathrm{y}+1 / 2,-\mathrm{z}+1 / 2$ (iii) $-\mathrm{x},-\mathrm{y}+1,-\mathrm{z}+1$ (iv) $\mathrm{x},+\mathrm{y}+1,+\mathrm{z}$

$\begin{array}{lllll}\mathbf{5} & & & & \\ \mathrm{O} 8-\mathrm{H} 8 \mathrm{~A} \cdots \mathrm{O} 2 & 0.80 & 1.851 & 2.617 & 159 \\ \mathrm{O} 8-\mathrm{H} 8 \mathrm{~B} \cdots \mathrm{O} 7 & 0.90 & 1.825 & 2.724 & 173 \\ \mathrm{C} 27-\mathrm{H} 27 \cdots \mathrm{O} 2 & 0.95 & 2.492 & 2.794 & 98 \\ \mathrm{C} 31-\mathrm{H} 31 \cdots \mathrm{O} 1 & 0.95 & 2.489 & 2.788 & 98 \\ \mathrm{O} 7-\mathrm{H} 7 \cdots \mathrm{O} 6 & 0.84 & 2.748 & 1.940 & 161 \\ \mathrm{C} 3-\mathrm{H} 3 \cdots \mathrm{O} 2^{\mathrm{i}} & 0.95 & 2.695 & 3.642 & 174 \\ \mathrm{C} 10-\mathrm{H} 10 \cdots \mathrm{O} 1^{\mathrm{i}} & 0.95 & 2.583 & 3.441 & 150 \\ \mathrm{C} 6-\mathrm{H} 6 \cdots 4^{\mathrm{i}} & 0.95 & 2.477 & 3.383 & 160 \\ \mathrm{C} 16-\mathrm{H} 16 \cdots \mathrm{O} 2^{\mathrm{ii}} & 0.95 & 2.512 & 3.439 & 165\end{array}$

Symmetry codes: (i) $\mathrm{x},-\mathrm{y}+1 / 2,+\mathrm{z}-1 / 2$ (ii) $\mathrm{x},-\mathrm{y}+1 / 2,+\mathrm{z}+1 / 2$

$\mathrm{Mn}(\mathrm{II})$ is coordinated by six $\mathrm{N}$ atoms from three phen molecules to complete a distorted $\mathrm{ZnN6}$ octahedral geometry. The $\mathrm{Mn}-\mathrm{N}$ bond lengths are in the range $2.238(3)-2.291(2) \AA$ and in good agreement with previous reports (table 2). The ligands form a distorted octahedral coordination sphere around $\mathrm{Mn}(\mathrm{II})$, with the bipy groups exhibiting their usual acute $\mathrm{N} \cdots \mathrm{N}$ bite distances $(\mathrm{N} 1 \cdots \mathrm{N} 2=2.686(3) \AA, \mathrm{N} 3 \cdots \mathrm{N} 4=$ 2.684(3) $\AA$, and $\mathrm{N} 5 \cdots \mathrm{N} 6=2.701(3) \AA$ ) and $\mathrm{N}-$ $\mathrm{Mn}-\mathrm{N}$ bite angles $\left(\mathrm{N} 1-\mathrm{Mn} 1-\mathrm{N} 2=73.07(8)^{\circ}\right.$, $\mathrm{N} 3-\mathrm{Mnl}-\mathrm{N} 4=74.61(8)^{\circ}$ and N5 $-\mathrm{Mnl}-$ N6 $\left.73.92(8)^{\circ}\right)$. The values are very close to those 


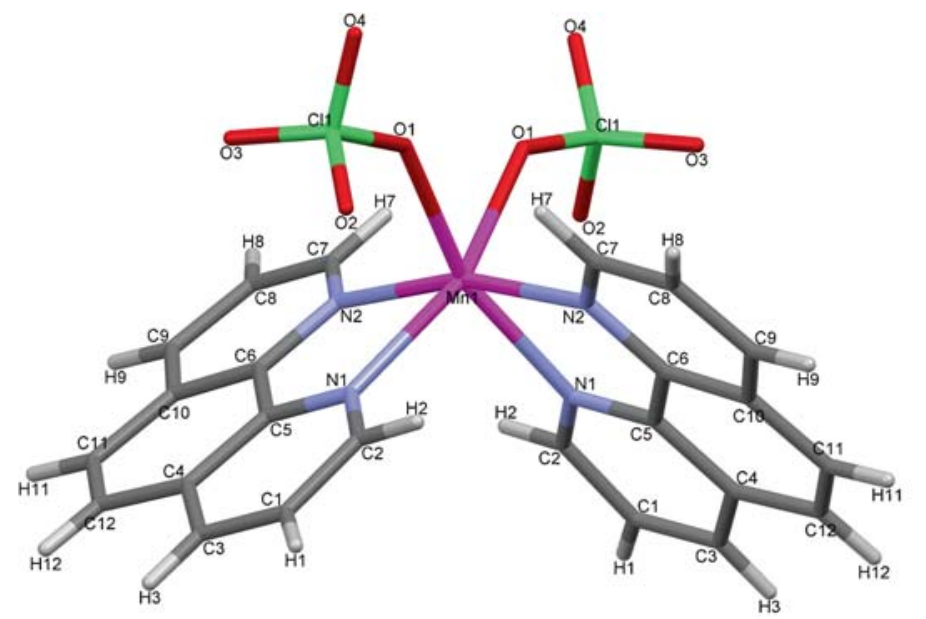

(a)

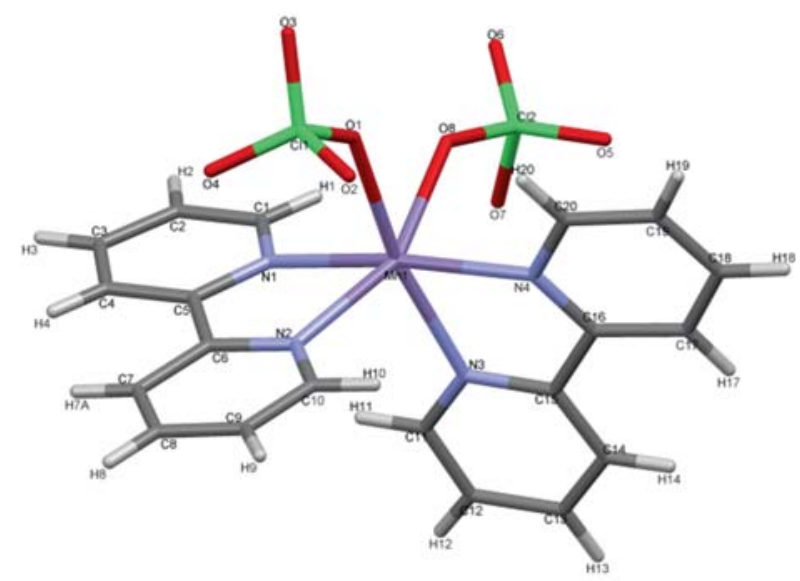

(b)

Figure 1. a) Molecular structure of complex 1. b) Molecular structure of complex 3.
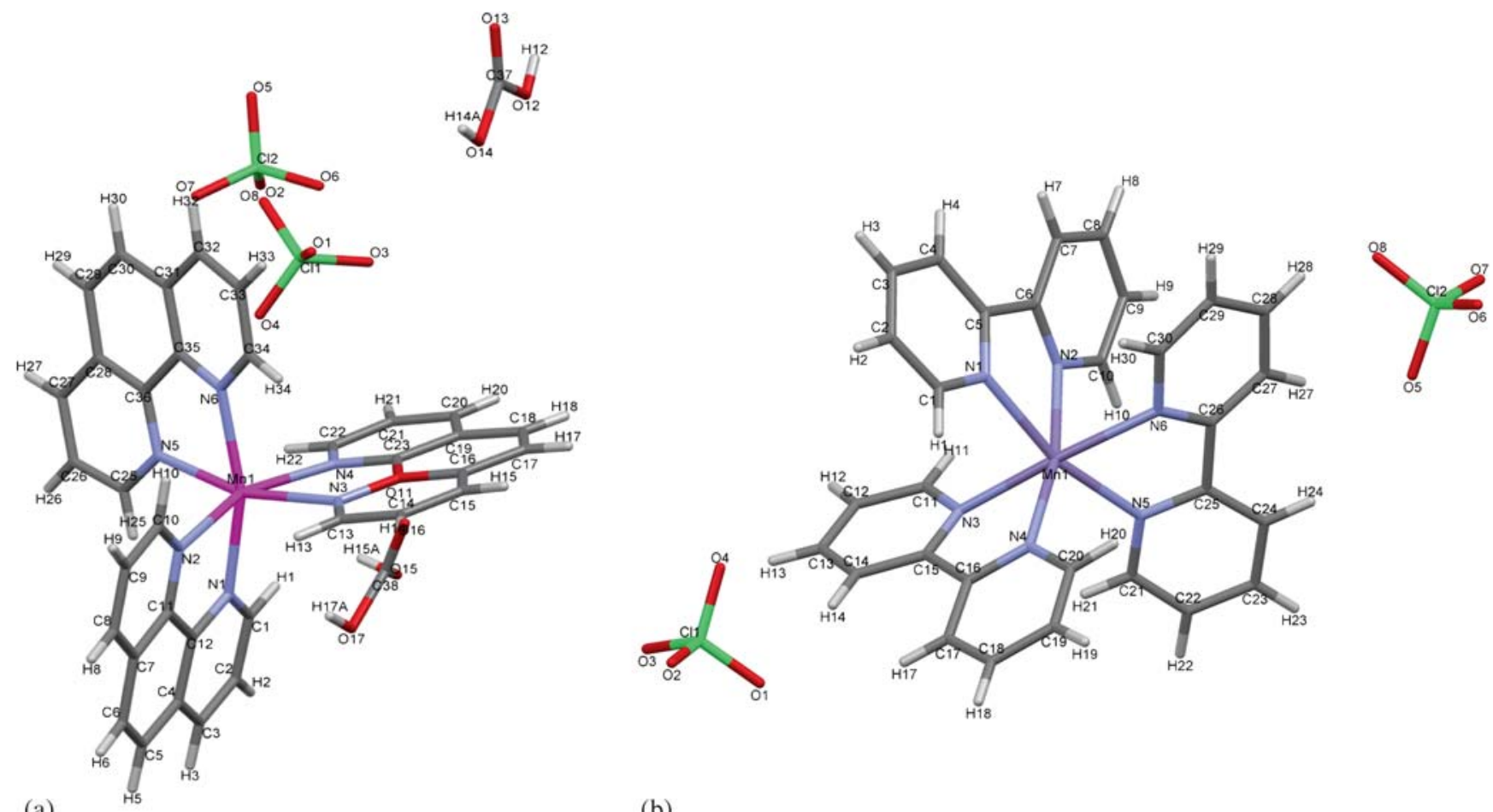

(b)

Figure 2. a) Molecular structure of complex 2. b) Molecular structure of complex 4 .

found in $\left[\mathrm{Mn}(\text { bipy })_{2} \mathrm{Cl}_{2}\right],{ }^{42,43} \quad\left[\mathrm{Mn}(\text { bipy })_{2}(\mathrm{NCS})_{2}\right]^{44}$ and $\left[\mathrm{Mn}(\mathrm{phen})_{2}\left(\mathrm{H}_{2} \mathrm{O}\right)\left(\mathrm{ClO}_{4}\right)\right] .{ }^{39}$ The deviations from ideal octahedral bond angles (table 1) are a consequence of chelate ring formation: cisoidal angles (73.07 $\left.-106.80(8)^{\circ}\right)$ and transoid angles $\left(164.48^{\circ}, 168.40^{\circ}\right.$, and $\left.175.13(8)^{\circ}\right)$. The 5-membered chelating rings of $\mathrm{Mn}(\mathrm{II})$ and bipy $\mathrm{N}$ atoms are not planar. The N1 - C5 - C6 $\mathrm{N} 2, \mathrm{~N} 3-\mathrm{C} 15-\mathrm{C} 16-\mathrm{N} 4$ and N5 - C25 - C26 $\mathrm{N} 6$ torsion angles are $20.6(3)^{\circ}, 13.8(3)^{\circ}$, and $24.4(3)^{\circ}$, respectively. The aromatic bond distances of the three bipy molecules are normal, within the range 1.336(3)1.360(3) $\AA$ for aromatic N - C bonds.
No classical hydrogen bonding was found in the crystal structure (table 3 ). $\mathrm{C}_{\text {bipy }}-\mathrm{H} \cdots \mathrm{O}$ hydrogen bonds between the oxygen atoms $(\mathrm{O} 1, \mathrm{O} 4, \mathrm{O} 6$ and $\mathrm{O} 7)$ of uncoordinated perchlorate anions and the hydrogen atoms of coordinated bipy are in the range $2.349 \AA$ to $2.556 \AA$. The closest intermolecular contact is observed between the carbon atom (C13) of bipy and the oxygen atoms of perchlorate $\mathrm{O} 1(3.101 \AA ;-\mathrm{x}+1,+\mathrm{y}+$ $1 / 2$ ). The shortest centroid-centroid distance of parallel bipy ligands is $4.665 \AA$. The existence of these stacking interactions confirms the formation of a 3D molecular network. The shortest metal-metal distance is $7.931 \AA$. 


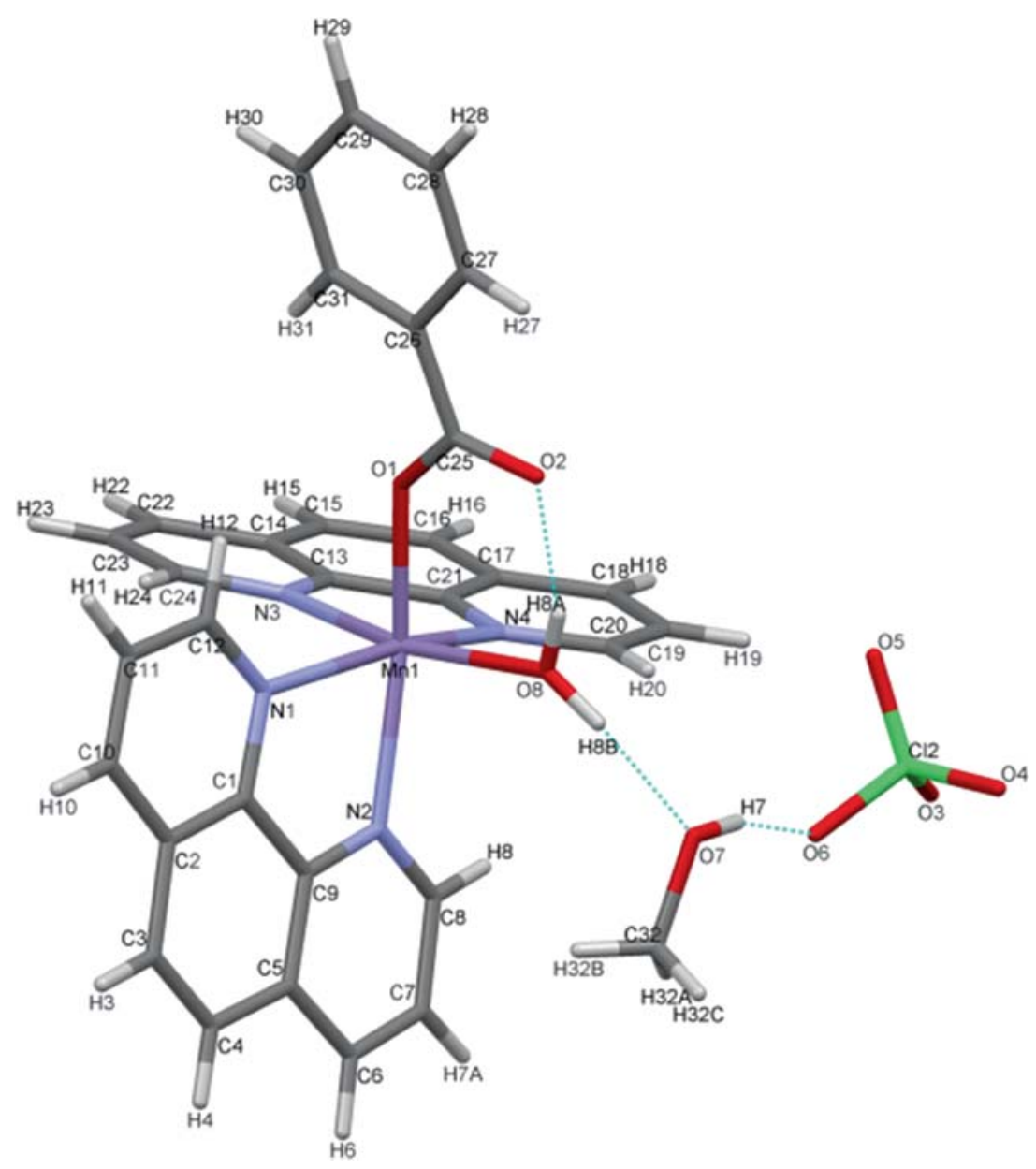

Figure 3. Molecular structure of complex 5.

3.3d $\left[\mathrm{Mn}(\text { phen })_{2}(\mathrm{ba})\left(\mathrm{H}_{2} \mathrm{O}\right)\right]\left(\mathrm{ClO}_{4}\right),(\mathbf{5})$ : Complex 5 crystallizes in the monoclinic space group P121/c1 (Z $=4)$. The X-ray structure for $\mathbf{5}$ is shown in figure 3 . The asymmetric unit consists of $\left[\mathrm{Mn}(\mathrm{ba})(\mathrm{phen})_{2}\left(\mathrm{H}_{2} \mathrm{O}\right)\right]$ (figure 3). The two phen ligands are coordinated to the $\mathrm{Mn}$ (II) in a bidentate manner, while the benzoate anion is bound to the metal through only one carboxylate oxygen in a monodentate mode. A water molecule occupies the sixth coordination site.

The Mn-O bond lengths are 2.162(2) $\AA$ and 2.108(1) $\AA$ whereas the $\mathrm{Mn}-\mathrm{N}$ distances are in the range 2.262(2) - 2.278(1) $\AA$; these distances are comparable to those reported elsewhere. ${ }^{36,42-44}$ The deviation from the ideal octahedral geometry is revealed by the range of angles observed around the metal center $\left(73.10(5)^{\circ}-103.45(5)^{\circ}\right)$ and by the transoid bond-angles $\left(160.93(5)^{\circ}, 161.21(5)^{\circ}\right.$ and $\left.163.19^{\circ}(6)\right)$ (table 3$)$. The phen groups exhibit their usual acute $\mathrm{N} \cdots \mathrm{N}$ bite distance $[\mathrm{N} 1 \cdots \mathrm{N} 2=2.708(2)$ and $\mathrm{N} 3 \cdots \mathrm{N} 4=2.707(2) \AA$, ] and $\mathrm{N}-\mathrm{Mn}-\mathrm{N}$ bite angles $\left(\mathrm{N} 1-\mathrm{Mn} 1-\mathrm{N} 2=73.10(8)^{\circ}\right.$ and N3 $-\mathrm{Mnl}-\mathrm{N} 4=$ $\left.73.38(8)^{\circ}\right)$. The phen ligands are perfectly planar. The 5-membered chelating rings of $\mathrm{Mn}(\mathrm{II})$ and $\mathrm{N}$ atoms of phen are not planar; the $\mathrm{N} 1-\mathrm{C} 1-\mathrm{C} 9-\mathrm{N} 2$ and $\mathrm{N} 3-\mathrm{C} 13-\mathrm{C} 21-\mathrm{N} 4$ torsion angles are $-0.7(2)^{\circ}$ and $1.3(2)^{\circ}$, respectively. The angles between the two planes on which the two phen ligands lie are $74.57^{\circ}$ and $71.07^{\circ}$ and $88.54^{\circ}$ for the benzoate ring and phen ligands, respectively.

Within the crystal lattice of $\mathbf{5}$, carboxylate oxygen $(\mathrm{O} 1)$, coordinated water oxygen $(\mathrm{O} 8)$, lattice perchlorate $(\mathrm{O} 3-\mathrm{O} 5)$, and methanol oxygens $(\mathrm{O} 7)$ are all involved in hydrogen bonding (table 3 ). The oxygen atoms (O4 and $\mathrm{O6}$ ) of uncoordinated perchlorate and the carboxylate group of ba $(\mathrm{O} 1$ and $\mathrm{O} 2)$ show the $\mathrm{C}-\mathrm{H} \cdots \mathrm{O}$ intermolecular interactions with hydrogen atoms of coordinated phen molecules in the range of $2.583 \AA$ to $2.748 \AA$ (table 3 ). The shortest $\pi \cdots \pi$ distance between 2 parallel phen ligands is $3.533 \AA$.

\subsection{Catalase Activity}

The catalytic activities of complexes $\mathbf{1}$ - $\mathbf{5}$ toward $\mathrm{H}_{2} \mathrm{O}_{2}$ disproportionation were investigated in acetonitrile, acetone and water (table 4 and figure 4). The initial solution of $\mathrm{Mn}(\mathrm{II})$ complexes is colorless, and after the 
Table 4. $\mathrm{H}_{2} \mathrm{O}_{2}$ disproportionation with $\mathbf{1}-\mathbf{5}$ in different solvents.

\begin{tabular}{lcccccc}
\hline Complex & Acetone $\left(\times 10^{-5} \mathrm{M} . \mathrm{s}^{-1}\right)$ & $\mathrm{TOF}\left(\mathrm{h}^{-1}\right)$ & Acetonitrile $\left(\times 10^{-5} \mathrm{M} \cdot \mathrm{s}^{-1}\right)$ & $\mathrm{TOF}\left(\mathrm{h}^{-1}\right)$ & Water $\left(\times 10^{-5} \mathrm{M} \cdot \mathrm{s}^{-1}\right)$ & $\mathrm{TOF}\left(\mathrm{h}^{-1}\right)$ \\
\hline $\mathbf{1}$ & 39.3 & 1518 & 5.08 & 195 & 4.06 & 366 \\
$\mathbf{2}$ & 39.2 & 1511 & 8.74 & 337 & 6.63 & 256 \\
$\mathbf{3}$ & 21.9 & 822 & 2.84 & 110 & 9.47 & 366 \\
$\mathbf{4}$ & 25.8 & 979 & 3.79 & 146 & 7.96 & 307 \\
$\mathbf{5}$ & 57.4 & 2193 & 20.3 & 728 & 8.74 & 366 \\
\hline
\end{tabular}
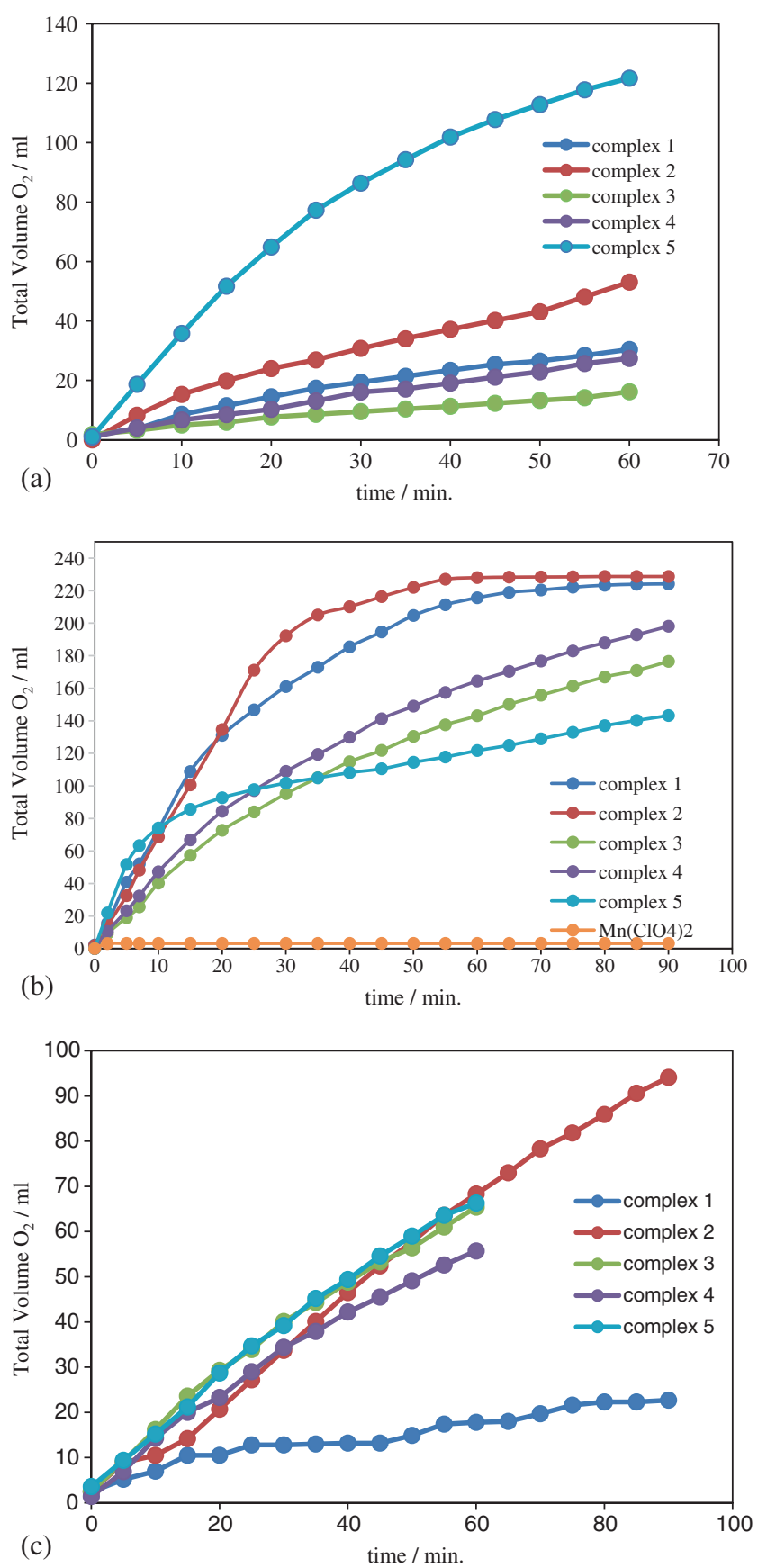

Figure 4. Time dependence of $\mathrm{O}_{2}$ evolution upon reaction of complexes 1-5 with $\mathrm{H}_{2} \mathrm{O}_{2}$ in different solvents. a) acetonitrile, b) acetone and c) water. Reaction conditions: catalyst $=$ $8.83 \times 10^{-3} \mathrm{~mol} ; \mathrm{H}_{2} \mathrm{O}_{2}=1.94 \times 10^{-2} \mathrm{~mol} ;$ solvent $=10$ $\mathrm{mL} ; \mathrm{T}=$ r.t. addition of $\mathrm{H}_{2} \mathrm{O}_{2}$, it becomes yellow or colorless and immediate evolution of oxygen was observed for all the complexes. Volumetric measurements of the evolved $\mathrm{O}_{2}$ show that these complexes are able to catalytically disproportionate $\mathrm{H}_{2} \mathrm{O}_{2}$ into $\mathrm{H}_{2} \mathrm{O}$ and $\mathrm{O}_{2}$. The degree of conversion is different for each compound. The catalytic activity of $\mathrm{Mn}\left(\mathrm{ClO}_{4}\right)_{2}$ towards $\mathrm{H}_{2} \mathrm{O}_{2}$ disproportionation was also investigated under the same conditions as those used for the Mn(II) compxesl. In this case, as shown in figure $4 b, 100 \%(T O F=1511)$ of the $\mathrm{H}_{2} \mathrm{O}_{2}$ decomposed using complex 2 whereas $\sim 1 \%$ of the $\mathrm{H}_{2} \mathrm{O}_{2}$ decomposed using the simple salt $\left(\mathrm{Mn}\left(\mathrm{ClO}_{4}\right)_{2}\right)$.

We observed that the presence of bidentate chelating NN donor ligands, bipy and phen in the coordination sphere of the metal not only significantly enhances the ability of the manganese to disproportionate $\mathrm{H}_{2} \mathrm{O}_{2}$ but also inhibits the formation of insoluble manganese oxide in acetone. The activities of complexes $\mathbf{1}$ and $\mathbf{3}$, which have four $\mathrm{N}$ atom coordinations, are $v_{\mathrm{o}}=39.3 \times$ $10^{-5} \mathrm{M} . \mathrm{s}^{-1}$, TOF $=1518 \mathrm{~h}^{-1}$ and $v_{\mathrm{o}}=21.0 \times 10^{-5}$ M.s ${ }^{-1}$, TOF $=822 \mathrm{~h}^{-1}$, respectively, and for complexes 2 and 4, which have six $\mathrm{N}$ atom coordinations, they are $v_{0}=39.2 \times 10^{-5} \mathrm{M} \cdot \mathrm{s}^{-1}$, TOF $=1511 \mathrm{~h}^{-1}$ and $v_{\mathrm{o}}=25.8 \times 10^{-5} \mathrm{M} \cdot \mathrm{s}^{-1}, \mathrm{TOF}=979 \mathrm{~h}^{-1}$, respectively (table 4). Furthermore, we observed that the nature of the ligands has a greater effect on the catalase activity. Complexes 1 and 2, which have more basic phen ligands, are more active in the disproportionation of $\mathrm{H}_{2} \mathrm{O}_{2}$ (TOF 1511 and $1518 \mathrm{~h}^{-1}$, respectively) than the bipy complexes of 3 and 4 (TOF 822 and $979 \mathrm{~h}^{-1}$, respectively), which have less basic bipy ligands. In addition, the disproportionation of $\mathrm{H}_{2} \mathrm{O}_{2}$ is almost two times faster for three coordinations than two coordinations of corresponding ligands (table 5). These results suggested that the number of $\sigma$-donors at the metal center is important to activate the hydrogen peroxide. ${ }^{45}$ Furthermore, complex 1 which contains benzoate and phen ligands has the highest TOF with $2193 \mathrm{~h}^{-1}$.

When the reaction was carried out at $37^{\circ} \mathrm{C}$ in Tris$\mathrm{HCl}$ buffer solution, which corresponds to the physiological conditions of the cell environment, the catalase activity of 2 gave an oxygen evolution rate of $1.26 \times$ $10^{-4} \mathrm{M} . \mathrm{s}^{-1}$. Thus, we suggest that complex 2 would also be an active catalyst in vitro. 
3.4a Solvent effect: The examination of the solvent effects was performed using acetone, acetonitrile and water to better understand the reaction. We observed that the decomposition rate of $\mathrm{H}_{2} \mathrm{O}_{2}$ by complexes 1-5 was found to depend strongly on the solvent. No induction period was observed in any of the studied solvents. The observed initial rates (under the same conditions) are given in table 4 , while figure 4 illustrates the data obtained in acetonitrile, acetone and water. The results showed that as the solvent polarity increased, the rate of disproportionation decreased (table 4). While $\mathrm{H}_{2} \mathrm{O}_{2}$ was disproportionated slowly in water, the reaction in acetone gave the best results for all complexes. The rates for $\mathbf{1}, \mathbf{2}, \mathbf{3}, \mathbf{4}$ and $\mathbf{5}$ were in the range of 2.3 to 10 times faster than in water. The highest activity was observed

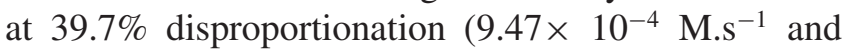
TOF $=366 \mathrm{~h}^{-1}$ ) over 90 min for complex 2 in water. Based on the solvent studies, it can be concluded that the rate of disproportionation decreases with the coordinating capacity of the solvent; the poorly coordinating acetone results in a higher rate than the strongly coordinating water or acetonitrile. We assume that this effect would indicate the presence of coordinatively saturated species within the catalytic cycle and that these intermediate species are probably stabilized by the coordination of solvent molecules, which are in a competition with the substrate for a vacant coordination site. In contrast to other complexes, complex $\mathbf{5}$, which is coordinated with one benzoate, two phen, and one water ligand, has the best activity (TOF $=728 \mathrm{~h}^{-1}$ ) in acetonitrile (table 4).

\subsection{Biological activity}

MICs were recorded as the minimum concentration of a compound that inhibits the growth of the tested microorganism. The antimicrobial and antifungal (anticandidal) activity of complexes 1-5, the metal-free ligands and a simple manganese salt were investigated. In this study, it was observed that benzoic acid and the simple salt $\left(\mathrm{Mn}\left(\mathrm{ClO}_{4}\right)_{2}\right.$ do not exhibit antimicrobial activities in the studied concentration range. Furthermore, the coordination of the acid to the metal (complex 5) does not result in any significant improvement in their activity.

When the antimicrobial activity of the metal complexes was investigated, the following factors should be considered: (i) the chelating effect of the ligands, (ii) the nature of donor ligands, (iii) the charge of the complex, (iv) the existence and the nature of the counter ion, and (v) the oxidation state of the metal in the complex. For complexes 1-5, only the first of these factors is present. ${ }^{46}$ Examination of the structure-activity relationships of the studied complexes indicates that the presence and number of chelating $\mathrm{NN}$ ligand and the oxygen donor ligand effect were the likely contributing factors to the activities of the compounds.

3.5a Antifungal activity: The antifungal activity of the complexes were tested on six different Candida species that are pathogenic to humans. Complexes $\mathbf{1}-\mathbf{5}$ showed higher inhibitory levels $(7.81 \mu \mathrm{g} / \mathrm{ml})$ than both the ligands (bipy, ba and salt) and the reference drug ketoconazole (table 5).

In contrast to the remarkable activity of 1,10 phenanthroline and its metal complexes, metal-free bipy and the majority of its metal complexes had no inhibitory effect on the growth of the studied microorganisms with the exception of complex $\mathbf{3}$ for C. krusei. Complexes $\mathbf{1}$ and $\mathbf{2}$ incorporating the phen ligand dramatically inhibit the growth of the fungus. Metal-free phen showed very high anti-Candidal activity, which was surpassed by the activity of phen complex 2 for

Table 5. Minimum inhibitory concentration (MIC, $\mu \mathrm{g} / \mathrm{ml})$ shown by studied compounds against the test fungi.

\begin{tabular}{lcccccc}
\hline Fungi & $\begin{array}{c}\text { Candida } \\
\text { tropicalis }\end{array}$ & $\begin{array}{c}\text { Candida } \\
\text { krusei }\end{array}$ & $\begin{array}{c}\text { Candida } \\
\text { zeylanoides }\end{array}$ & $\begin{array}{c}\text { Candida } \\
\text { parapsilosis }\end{array}$ & $\begin{array}{c}\text { Candida } \\
\text { albicans }\end{array}$ & $\begin{array}{c}\text { Candida } \\
\text { globrata }\end{array}$ \\
\hline$\left.\left[\mathrm{Mn}(\mathrm{phen})_{2}\left(\mathrm{ClO}_{4}\right)_{2}\right)\right], \mathbf{1}$ & 15.625 & 7.8125 & 62.5 & 15.625 & 15.625 & 7.8125 \\
$\left.\left[\mathrm{Mn}(\mathrm{phen})_{3}\right]\left(\mathrm{ClO}_{4}\right)_{2}\right)_{2}$ & 7.8125 & 7.8125 & 31.25 & 15.625 & 7.8125 & 15.625 \\
$\left(\mathrm{H}_{2} \mathrm{CO}_{3}\right), 2$ & & & & & \\
{$\left[\mathrm{Mn}\left(2,2^{\prime}-\text {-bipy }\right)_{2}\left(\mathrm{ClO}_{4}\right)_{2}\right], \mathbf{3}$} & 62.5 & 31.25 & 250 & 62.5 & 62.5 & 62.5 \\
$\left.\left[\mathrm{Mn}\left(2,2^{\prime}-\text {-bipy }\right)_{3}\right]\left(\mathrm{ClO}_{4}\right)_{2}\right), \mathbf{4}$ & 62.5 & 31.25 & 250 & 62.5 & 62.5 & 125 \\
{$\left[\mathrm{Mn}(\mathrm{ba})(\mathrm{phen})_{2}\left(\mathrm{H}_{2} \mathrm{O}\right)\right]\left(\mathrm{ClO}_{4}\right)_{2}$} & 7.8125 & 7.8125 & 31.25 & 62.5 & 15.625 & 15.625 \\
$\left(\mathrm{CH} \mathrm{H}_{3} \mathrm{OH}\right), \mathbf{5}$ & & & & & & \\
bipy & 62.5 & 62.5 & 250 & 62.5 & 62.5 & 31.25 \\
phen & 7.8125 & 7.8125 & 15.625 & 31.25 & 15.625 & 15.625 \\
ba & 125 & 62.5 & 250 & 125 & 250 & 250 \\
Salt, $\left(\mathrm{Mn}\left(\mathrm{ClO}_{4}\right)_{2}\right.$ & 125 & 125 & 250 & 250 & 250 & 250 \\
Ketoconazole & 125 & 125 & 250 & 15.625 & 62.5 & 62.5 \\
\hline
\end{tabular}


C. tropicalis and C. zeylanoides. In addition to this result, increasing the number of chelating phen from 2 to 3 increases the inhibition effect for $C$ tropicalis, $C$. zeylanoides and $C$. albicans but does not affect the activity for C. krusei and C. parapsilosis. Furthermore, compared with the activity of complex $\mathbf{1}$, which has two chelating phen ligands, the addition of a second oxygen donor ligand ba does not affect the inhibition of metal complex 5 for $C$. krusei and C. albicans but increases inhibition for $C$. tropicalis and $C$. zeylanoides and decreases the inhibition of $C$. parapsilosis and $C$. glabrata.

The order of the antifungal activities of the compounds toward $C$. tropicalis was $\mathbf{2}=\mathbf{5}=$ phen $>\mathbf{1}>\mathbf{3}=$ $\mathbf{4}=$ bipy $>$ ba $=$ salt $=$ ketoconazole. $C$. krusei was more sensitive to the tested compounds than the other Candida species, and complexes 1, 2 and $\mathbf{5}$ had the same inhibitory concentration for the yeast. C. zeylanoides was more resistant to all of the compounds tested, but ligands $\mathbf{2}$ and $\mathbf{5}$ showed the highest concentrations. For C. parapsilosis, complexes $\mathbf{1}$ and $\mathbf{2}$ had the same activity as the reference drug, and the order of activity was the reference drug ketoconazole $=\mathbf{1}$ $=\mathbf{2}>$ phen $>\mathbf{3}=\mathbf{4}=\mathbf{5}=$ bipy $>$ ba $>$ salt. Complex 2 showed the highest MIC $(7.81 \mu \mathrm{g} / \mathrm{mL})$ toward $C$. albicans, while complexes $\mathbf{1}, \mathbf{5}$ and phen inhibited the growth of the fungus at $15.62 \mu \mathrm{g} / \mathrm{mL}$. The antifungal activity of the compounds toward C. glabrata was in the order of $\mathbf{1}>\mathbf{2}=\mathbf{5}=$ phen $>\mathbf{3}=$ ketoconazole $>\mathbf{4}>$ $\mathrm{ba}=$ salt.

It is possible that the differences in the activities of $\left[\mathrm{Mn}(\text { bipy })_{2}\left(\mathrm{ClO}_{4}\right)_{2}\right]$ and $\left[\mathrm{Mn}(\text { bipy })_{3}\right]^{+2}$ and also $\left[\mathrm{Mn}(\text { phen })_{2}\left(\mathrm{ClO}_{4}\right)_{2}\right]$ and $\left[\mathrm{Mn}(\text { phen })_{3}\right]^{+2}$ against bacteria are greatly influenced by the differences in the abilities of these two species to traverse cell walls and/or membrane construction. It is expected that the more extensive aromatic ring system of the phen ligand, compared to bipy would confer greater lipophilicity to $\left[\mathrm{Mn}(\text { phen })_{2}\left(\mathrm{ClO}_{4}\right)_{2}\right]$ and $\left[\mathrm{Mn}(\text { phen })_{3}\right]^{+2}$ and enable it to penetrate the cell wall and promote adverse intracellular interactions. The toxicity increase may be considered in the light of Tweedy's chelation theory. ${ }^{46}$ Chelation considerably reduces the polarity of the metal ion because of partial sharing of its positive charge with oxygen and nitrogen donor atoms and possible $\pi$-electron delocalization over the entire chelate ring. Such a chelation could enhance the lipophilic nature of the complex, which subsequently favors its permeation through the lipid cell membrane, thus enhancing its antibacterial and antifungal activities. ${ }^{47-50}$

3.5b Antibacterial activity: The antibacterial experimental data (table 6) indicate that $P$. aeroginosa and $P$. vulgaris were the most resistant bacteria against all of the compounds tested, including the reference drug, and the MIC values of all of the compounds were found to be in the range $125-250 \mu \mathrm{g} / \mathrm{mL}$. However, other bacteria tested were moderately sensitive to the compounds at 15.62 and $31.25 \mu \mathrm{g} / \mathrm{mL}$. The antibacterial activities of the compounds toward $S$. aureus were found to follow the order $\mathbf{1}>\mathbf{2}=\mathbf{5}>\mathbf{3}>\mathbf{4}=$ bipy $=$ ba $=$ salt. $K$. pneumonia was the most sensitive to phen, and complexes 1, 2 and $\mathbf{5}$ showed the same level of antibacterial activity. The antibacterial activity of the compounds toward E. coli were found to follow the order standard chloramphenicol $>\mathbf{2}=$ phen $>\mathbf{1}=\mathbf{5}>$ bipy $>\mathbf{3}=\mathbf{4}$ $>$ ba $=$ salt. For L. monocytogenes, the order of activity can be arranged in the following order: standard chloramphenicol $>$ phen $>\mathbf{1}=\mathbf{2}=\mathbf{5}>\mathbf{4}>$ bipy $=$ $\mathrm{ba}=$ salt $>3$. It can be concluded that derivatization of the ligands resulted in the higher antibacterial activations of complexes $\mathbf{1}, \mathbf{2}$ and $\mathbf{5}$. Although there are sufficient increases in the antibacterial activities of the

Table 6. Minimum inhibitory concentration (MIC, $\mu \mathrm{g} / \mathrm{mL})$ shown by studied compounds against the test bacteria.

\begin{tabular}{|c|c|c|c|c|c|c|c|}
\hline $\begin{array}{l}\text { Bacterium } \\
\text { chemical }\end{array}$ & S. aureus & P. aeroginosa & K. pneumonie & E. coli & E. feacalis & $\begin{array}{l}\text { Proteus } \\
\text { vulgaris }\end{array}$ & L. Monocytogenes \\
\hline$\left.\left[\mathrm{Mn}(\text { phen })_{2}\left(\mathrm{ClO}_{4}\right)_{2}\right)\right], \mathbf{1}$ & 31.25 & 250 & 31.25 & 31.25 & 31.25 & 250 & 31.25 \\
\hline $\begin{array}{l}\left.\left[\mathrm{Mn}(\mathrm{phen})_{3}\right]\left(\mathrm{ClO}_{4}\right)_{2}\right)_{2} \\
\left(\mathrm{H}_{2} \mathrm{CO}_{3}\right), 2\end{array}$ & 62.5 & 250 & 31.25 & 15.625 & 31.25 & 125 & 31.25 \\
\hline$\left.\left[\mathrm{Mn}\left(2,2^{\prime}-\mathrm{bipy}\right)_{2}\left(\mathrm{ClO}_{4}\right)_{2}\right)\right], \mathbf{3}$ & 125 & 250 & 125 & 125 & 125 & 250 & 250 \\
\hline$\left.\left[\mathrm{Mn}\left(2,2^{\prime} \text {-bipy }\right)_{3}\right]\left(\mathrm{ClO}_{4}\right)_{2}\right), 4$ & 250 & 250 & 125 & 125 & 62.5 & 250 & 62.5 \\
\hline $\begin{array}{l}{\left[\mathrm{Mn}(\mathrm{ba})(\mathrm{phen})_{2}\left(\mathrm{H}_{2} \mathrm{O}\right)\right]\left(\mathrm{ClO}_{4}\right)_{2}} \\
\left(\mathrm{CH}_{3} \mathrm{OH}\right), \mathbf{5}\end{array}$ & 62.5 & 250 & 31.25 & 31.25 & 62.5 & 250 & 31.25 \\
\hline bipy & 250 & 250 & 125 & 62.5 & 62.5 & 250 & 125 \\
\hline phen & 31.25 & 250 & 15.625 & 15.625 & 15.625 & 125 & 15.625 \\
\hline ba & 250 & 250 & 250 & 250 & 250 & 250 & 125 \\
\hline salt, $\left(\mathrm{Mn}\left(\mathrm{ClO}_{4}\right)_{2}\right.$ & 250 & 250 & 250 & 250 & 250 & 250 & 125 \\
\hline Chloramfenicol & 3.906 & 125 & 7.812 & 7.812 & 7.812 & 15.625 & 3.906 \\
\hline
\end{tabular}


manganese complexes compared to free phen ligands, it could not reach the effectiveness of the conventional chloramphenicol.

It would appear that bipy, whether coordinated or uncoordinated to manganese, does not improve antiCandidal properties. Furthermore, the presence and number of NN-donor phen significantly improves the activity of the complex. The phen molecule is a potent anti-Candidal agent and, upon reaction with $\mathrm{Mn}(\mathrm{II})$, yields complexes with comparable fungi-toxic activities. Finally, complexes 1, 2 and $\mathbf{5}$ have the potential as alternative antifungal drugs to ketoconazole for the treatment of Candida infections. All of the synthesized complexes have reasonable antimicrobial activities. However, a different set of microorganisms could be involved in further antimicrobial activity tests because different genera and species, or even strains, could have different degrees of sensitivity to these antimicrobials.

\section{Conclusions}

In this study, the syntheses, crystal structures and biological/catalase-like activities of five $\mathrm{Mn}$ (II) complexes with two or three neutral ligands are presented. Complexes 1 and 3 contain two 1,10-phenanthroline/ 2,2'-bipyridine ligands, and complexes $\mathbf{2}$ and $\mathbf{4}$ contain three 1,10-phenanthroline/2,2'-bipyridine ligands, while complex 5 contains 1,10-phenanthroline and benzoic acid. The effects of NN chelating neutral ligands with $\mathrm{Mn}$ (II) on biological and catalase-like activities were investigated. All complexes have higher activities in acetone than in acetonitrile and water. Complex $\mathbf{5}$ showed the maximum TOF followed by 1, 2, 4 and 3 in acetone. Complexes containing phen ligands (i.e., $\mathbf{1}$ and 2) are more active in the disproportionation of $\mathrm{H}_{2} \mathrm{O}_{2}$ than bipy complexes ( $\mathbf{3}$ and $\mathbf{4})$. The rate of reaction was 1.5 times faster for three-coordinated phen than bipy and 1.8 times faster for two-coordinated phen than bipy ligands. Biological activity studies showed that bipy containing complexes ( $\mathbf{3}$ and $\mathbf{5})$ are less active than phen containing complexes (1, 2 and $\mathbf{5})$ and the latter complexes have the potential to be alternative antifungal drugs to ketoconazole for the treatment of Candida infections.

\section{Supplementary Information (SI)}

CCDC 808526, 848864, 848417, 798813 and 827692 contain the supplementary crystallographic data for complexes $\mathbf{1}-\mathbf{5}$, respectively. These data can be obtained free of charge via http://www.ccdc.cam.ac. uk/conts/retrieving.html, or from the Cambridge Crystallographic Data Centre, 12 Union Road, Cambridge CB2 1EZ, UK; fax: (+44) 1223-336-033; or e-mail: deposit@ccdc.cam.ac.uk. FTIR spectra and UV-Vis spectra are available in Supplementary Information at www.ias.ac.in.chemsci.

\section{Acknowledgements}

The authors are grateful to Anadolu University and the Medicinal Plants and Medicine research Centre of Anadolu University, Eskişehir, Turkey, for the use of Xray Diffractometer. This work was supported by BAP (1106F1123) funded by Anadolu University.

\section{References}

1. Ronconi L and Sadler P J 2007 Coord. Chem. Rev. 251 1633

2. Storr T, Thompson K H and Orvi C 2006 Chem. Soc. Rev. 35534

3. Guo Z and Sadler P J 1999 Angew. Chem. Int. Ed. 38 1512

4. Lippert B 1999 In Cisplatin: Chemistry and Biochemistry of a Leading Anticancer Drug (New York: John Wiley)

5. Tapiero H and Tew K D 2003 Biomed. Pharmacother. 57399

6. Biswas B, Kole N, Patra M, Shampa Dotta S and Ganguly M 2013 J. Chem. Sci. 1251445

7. Patel M N, Joshi H N and Patel C R 2014 J. Chem. Sci. 126739

8. Fukuda Y and Sone K 1970 Bull. Chem. Soc. Jpn. 43 556

9. Bailey N A, Fenton D E, Franklin M V and Hall M 1980 J. Chem. Soc. Dalton. Trans. 984

10. Madalan A M, Kravtsov V C, Pajic D, Zadro K, Simonov Y A, Stanica N, Ouahab L, Lipkowski J and Andruh M 2004 Inorg. Chim. Acta 3574151

11. Paulovicova A, El-Ayaan U and Fukuda Y 2001 Inorg. Chim. Acta 32156

12. Triller M U, Hsieh W Y, Pecoraro V L, Rompel A and Krebs B 2002 Inorg. Chem. 45544

13. Wu A J, Penner-Hahn J E and Pecoraro V L 2004 Chem. Rev. 104903

14. Reddig N, Pursche D, Kloskowski M, Slinn C, Baldeau S M and Rompel A 2004 Eur. J. Inorg. Chem. 879

15. Signorella S, Rompel A, Buldt-Karentzopoulos K, Krebs B, Pecoraro V L and Tuchagues J P 2007 Inorg. Chem. 4610864

16. Signorella S and Hureau C 2012 Coord. Chem. Rev. 256 1229

17. Biava H, Palopoli C, Duhayon C, Tuchagues J P and Signorella S 2009 Inorg. Chem. 483205

18. Biju A R and Rajasekharan M V 2011 Inorg. Chim. Acta 372275

19. Vázquez-Fernández M A, Bermejo M R, FernándezGarcía M I, González-Riopedre G, Rodríguez-Doutón M J and Maneiro M J 2011 Inorg. Biochem. 1051538 
20. Malik G S, Singh S P and Bisht N P S 1980 Curr. Sci. 49298

21. Coyle B, Kinsella P, McCann M, Devereux M, O'Connor R, Clynes M and Kavanagh K 2004 Toxicol. in Vitro 1863

22. De Vizcaya-Ruiz A, Rivero-Muller A, Ruiz-Ramirez L, Kass G, Kelland L R, Orr R M and Dobrota M 2000 Toxicol. in Vitro 141

23. Gurumoorthy P, Ravichandran J and Rahiman A K 2014 J. Chem. Sci. 126783

24. Gulea A, Poirier D, Roy J, Stavila V, Bulimestru I, Tapcov V, Birca M and Popovschi L 2008 J. Enzyme Inhib. Med. Chem. 23806

25. Qaiyumi S 2007 In Antimicrobial Susceptibility Testing Protocols $\mathrm{R}$ Schwalbe, L Steele-Moore and A C Goodwin (Eds.) (London: CRC Press)

26. SMART 2000 (Bruker Analytics 1 X-ray Systems Inc: Madison WI 53719 USA)

27. Sheldrick G M 1997 SHELXS-97 Program for crystal structure solution (Gottingen: University of Gottingen)

28. Sheldrick G M 1997 SHELXL-97 Program for crystal structure refinement (University of Gottingen: Gottingen)

29. Spek A L 2005 PLATON - A Multipurpose Crystallographic Tool (The Netherlands: Utrecht University)

30. Wickenden A E and Krause R 1965 Inorg. Chem. 4404

31. Hathaway B J and Underhill A E 1961 J. Chem. Soc. 3091

32. Nakamoto K 1986 In Infrared and Raman Spectra of Inorganic and Coordination Compounds $4^{\text {th }}$ edn. (New York: Wiley-Interscience)

33. Gurdip S, Inder P S K, Dinesh K, Udai P S and Nidhi G 2009 Inorg. Chim. Acta 3624091
34. McCann S, McCann M, Casey M T, Jackman M, Devereux M and McKee V 1998 Inorg. Chim. Acta 279 24

35. Zhenyu L, Duanjun X, Jingjing N, Zhiyong W, Jingyun W and Chiang M Y 2002 J. Coord. Chem. 55 1155

36. Rodriguez-Martin Y, Javier G P and Catalana R P 1999 Acta Cryst. C55 186

37. Malinowski T J, Kravtsov V C, Simonov Y A, Lipkowski J and Bologa O A 1996 J. Coord. Chem. 37 187

38. Zhao J, Zheng X G and Hu Z Z 2009 Acta Cryst. E65 $\mathrm{m} 1642$

39. Pan T T and Xu D 2005 Acta Cryst. E61 m740

40. Kani I and Kurtça M 2012 Turk. J. Chem. 36827

41. Cotton F A and Wilkinson G 1972 In Advanced Inorganic Chemistry (New York: John Wiley)

42. Paavo O L and Eva L 1988 Acta Cryst C44 463

43. Li Z Y, Xu D J, Nie J J, Wu Z Y, Wu J Y and Chiang M 2002 J. Coord. Chem. 551155

44. Veidis M V, Dockum B, Charron F F, Reiff W M and Brennan T F 1981 Inorg. Chim. Acta 53 L197

45. Boelrijk A EM and Dismukes G C 2000 Inorg. Chem. 393020

46. Tweedy B G 1964 Phytopathology 55910

47. Seven M J and Johnson L A 1960 In Metal Binding in Medicine 4th ed (Philadelphia PA: Lippincott)

48. Chohan Z H and Supuran C T 2005 Appl. Organometal. Chem. 191207

49. Chohan Z H, Arif M, Akhtar M A and Supuran C 2006 Bioinorg. Chem. Appl. 1

50. Raman N, Raja S J and Sakthivel A 2009 J. Coord. Chem. 62691 